\title{
Short- and long-term effects of ponderosa pine fuel treatments intersected by the Egley Fire Complex, Oregon, USA
}

\author{
Jessie M. Dodge ${ }^{*^{*}}$ D, Eva K. Strand ${ }^{1}$, Andrew T. Hudak², Benjamin C. Bright ${ }^{2}$, Darcy H. Hammond ${ }^{1}$ and
} Beth A. Newingham ${ }^{3}$

\begin{abstract}
Background: Fuel treatments are widely used to alter fuels in forested ecosystems to mitigate wildfire behavior and effects. However, few studies have examined long-term ecological effects of interacting fuel treatments (commercial harvests, pre-commercial thinnings, pile and burning, and prescribed fire) and wildfire. Using annually fitted Landsat satellite-derived Normalized Burn Ratio (NBR) curves and paired pre-fire treated and untreated field sites, we tested changes in the differenced NBR (dNBR) and years since treatment as predictors of biophysical attributes one and nine years after the 2007 Egley Fire Complex in Oregon, USA. We also assessed short- and longterm fuel treatment impacts on field-measured attributes one and nine years post fire.

Results: One-year post-fire burn severity (dNBR) was lower in treated than in untreated sites across the Egley Fire Complex. Annual NBR trends showed that treated sites nearly recovered to pre-fire values four years post fire, while untreated sites had a slower recovery rate. Time since treatment and dNBR significantly predicted tree canopy and understory green vegetation cover in 2008, suggesting that tree canopy and understory vegetation cover increased in areas that were treated recently pre fire. Live tree density was more affected by severity than by pre-fire treatment in either year, as was dead tree density one year post fire. In 2008, neither treatment nor severity affected percent cover of functional groups (shrub, graminoid, forb, invasive, and moss-lichen-fungi); however, by 2016, shrub, graminoid, forb, and invasive cover were higher in high-severity burn sites than in low-severity burn sites. Total fuel loads nine years post fire were higher in untreated, high-severity burn sites than any other sites. Tree canopy cover and density of trees, saplings, and seedlings were lower nine years post fire than one year post fire across treatments and severity, whereas live and dead tree basal area, understory surface cover, and fuel loads increased.

Conclusions: Pre-fire fuel treatments effectively lowered the occurrence of high-severity wildfire, likely due to successful pre-fire tree and sapling density and surface fuels reduction. This study also quantified the changes in vegetation and fuels from one to nine years post fire. We suggest that low-severity wildfire can meet prescribed fire management objectives of lowering surface fuel accumulations while not increasing overstory tree mortality.
\end{abstract}

Keywords: burn severity, fuel loadings, fuel treatments, invasive species, seedling regeneration, thinning, tree mortality, understory composition

\footnotetext{
* Correspondence: jessied@uidaho.edu

${ }^{1}$ Department of Forest, Rangeland, and Fire Sciences, University of Idaho, 875

Perimeter Drive, Moscow, Idaho 83844, USA

Full list of author information is available at the end of the article
} 


\section{Resumen}

Antecedentes: Los tratamientos de combustible son ampliamente usados para alterar los combustibles en ecosistemas forestales y mitigar el comportamiento y efectos de los incendios. Sin embargo, pocos estudios han examinado los efectos ecológicos a largo plazo de las interacciones entre tratamientos de combustibles (cosechas comerciales, raleos pre-comerciales, apilado y quema, y quemas prescritas) y los incendios. Usando curvas ajustadas anualmente de imágenes Landsat derivadas de la relación de quemado normalizado (Normalized Burn Ratio, NBR) y sitios a campo apareados tratados con quema y no tratados, probamos los cambios en las diferencias en NBR (dNBR) y años desde el tratamiento como predictores de los atributos biofísicos uno y nueve años después del incendio de 2007 Ilamado Egley Fire Complex, ocurrido en Oregon, EEUU. También determinamos los impactos de los tratamientos en el corto y largo plazo sobre los atributos medidos en los sitios de campo uno y nueve años después del incendio.

Resultados: Un año después del incendio, la severidad post fuego (dNBR) fue menor en los sitios tratados que en los no tratados a través del complejo del incendio Egley. La tendencia anual del NBR mostró que los sitios tratados casi recuperan los valores pre-fuego quatro años luego del incendio, mientras que los sitios no tratados tuvieron una tasa de recuperación más lenta. El tiempo desde el tratamiento y el dNBR predijeron significativamente la cobertura del dosel arbóreo y de la vegetación verde del sotobosque en 2008, sugiriendo que el dosel arbóreo y la cobertura del sotobosque se incrementaron en aquellas áreas que fueron tratadas inmediatamente previo al incendio. La densidad de árboles vivos fue más afectada por la severidad del incendio que por el tratamiento pre fuego en ambos años, como así también la densidad de árboles muertos un año después del incendio. En 2008, ni los tratamientos ni la severidad del incendio afectaron el porcentaje de cobertura de los grupos funcionales (arbustos, graminoides, hierbas, especies invasoras, y los musgos, líquenes y hongos); sin embargo para 2016, la cobertura de arbustos, graminoides, hierbas y especies invasoras fueron mayores en sitios afectados por alta severidad que en aquellos con baja severidad. La carga total de combustibles nueve años después del incendio fue mayor en áreas no tratadas y quemadas con alta severidad que en cualquier otro sitio. La cobertura del dosel arbóreo y la densidad de árboles, renovales, y plántulas disminuyeron más nueve años después del incendio que un año después del incendio en todos los tratamientos y severidades, mientras que el área basal de árboles vivos y muertos, la cobertura del sotobosque, y la carga de combustible aumentaron.

Conclusiones: Los tratamientos de combustible previos al incendio de Egley bajaron efectivamente la ocurrencia de fuegos de alta severidad, muy probablemente debido a que éstos redujeron exitosamente la densidad de árboles y renovales y también los combustibles de superficie. Este estudio también cuantificó los cambios en vegetación y combustibles de uno a nueve años posteriores al incendio. Sugerimos que incendios de baja severidad pueden lograr los objetivos del manejo del fuego prescrito bajando la acumulación de carga de combustibles superficiales sin incrementar la mortalidad de árboles del dosel superior.

\section{Abbreviations}

BARC: Burned Area Reflectance Classification

CWD: Coarse Woody Debris

DBH: Diameter at Breast Height

dNBR: differenced Normalized Burn Ratio

FWD: Fine Woody Debris

GEE: Google Earth Engine

LandTrendr: Landsat-based detection of trends in disturbance and recovery

MRBP: Blocked Multi-Response Permutation Procedure

MTBS: Monitoring Trends in Burn Severity

NBR: Normalized Burn Ratio

NPV: Non-Photosynthetic Vegetation

T: Treated

U: Untreated

\section{Background}

Many dry ponderosa pine (Pinus ponderosa Lawson \& C. Lawson) forests in the western United States frequently experienced natural thinning due to lowseverity surface fires prior to Euro-American settlement (Cooper 1960; Allen et al. 2002; Agee and Skinner 2005). Many established seedlings and saplings were often killed by low-severity surface fires, reducing fuel buildups (Bradley et al. 1992), but heat from the low-intensity flames rarely penetrated the thick bark enough to kill larger ponderosa pine trees (Cooper 1960; McCune 1988). Pine's ability to self-prune lower branches resists fire from reaching the tree bole, and their open, loosely arranged crowns aid in limiting crown combustion (Bradley et al. 1992). 
After Euro-American settlement, fire suppression efforts and change in land use, including grazing, logging, and road development, led to a decrease in lowseverity surface fires across much of the range of dry ponderosa pine (Covington and Moore 1994; Allen et al. 2002; Hessburg et al. 2005). The absence of frequent, low-severity surface fires has led to an accumulation of ladder fuels that carry flames into the crown (Allen et al. 2002), causing fires of higher severity, resulting in more ecological change in vegetation and soil compared to low-severity fires (Morgan et al. 2001; Lentile et al. 2006; Keeley 2009). Thus, many dry ponderosa pine forests have experienced a decrease in fire resilience, defined as an ecosystem's ability to recover to pre-fire state after a disturbance (Holling 1973; Groffman et al. 2006).

To reduce the size and severity of wildfires and restore fire resilience in ponderosa pine forests, many land managers have implemented fuel treatments, such as thinning and prescribed fire (Covington and Moore 1994; Fulé et al. 1997; Agee and Skinner 2005). When precommercial thinning is implemented as a fuel treatment, land managers focus on removing small-diameter trees to reduce stand density and to increase canopy base heights to exceed the flame length of surface fires. Prescribed surface fires are used to reduce surface fuels, small trees, and shrubs, much like fires in the historical, low-severity fire regimes of most ponderosa pine forests (Agee and Skinner 2005; Finney et al. 2005).

Silvicultural treatments such as commercial thinning and harvests can also reduce the risk of severe fire within certain timeframes (Chung 2015). Commercial activities will target larger trees (lower size limit of 15 $\mathrm{cm}$ ) for removal at various intensities, from full overstory removal (clearcut) to limited overstory removal (thinning), resulting in either an even- or uneven-aged stand (Agee and Skinner 2005). Although the primary goal of commercial harvests is typically for economic gain (Agee and Skinner 2005), harvests can act as a fuel treatment by reducing canopy fuels (Chung 2015), breaking up horizontal tree canopy continuity in dense areas (Agee and Skinner 2005)

Thinning has been shown to effectively reduce burn severity in ponderosa pine ecosystems (Agee and Skinner 2005; Stephens et al. 2009; Hudak et al. 2011b). Thinning of dense stands allows more sunlight to access the forest understory, generally increasing understory vegetation cover and diversity (Bartuszevige and Kennedy 2009; Schwilk et al. 2009; Stephens et al. 2012b). Thinning treatments tend to leave piles of slash that contribute to surface fuel loads and can increase burn severity in the event of a wildfire unless treated in a slash and pile burn (Graham et al. 1999; Hudak et al. 2011b). Burning of these slash piles in wildland or prescribed fires can cause localized severe effects on soil patches, thereby altering soil characteristics, reducing soil microbiota and soil seed bank viability, potentially leading to a decrease in native understory vegetation cover (Graham et al. 1999; Haskins and Gehring 2004; Korb et al. 2004). Soil disturbances caused by thinning may also increase invasive species cover (Korb et al. 2004; Dodson and Fiedler 2006; Stephens et al. 2012b).

Prescribed fires are generally less costly than thinning and have been shown to be more effective at reducing surface fuels than mechanical treatments in multiple ecosystems (Schwilk et al. 2009; Bernau et al. 2018). The burning of surface fuels aids in soil nutrient cycling and cues regeneration of fire-resilient species (Stephens et al. 2012b). However, smoke hazards to urban populations and air quality (Hardy et al. 2001), and liability concerns with fire escape into neighboring properties (Yoder et al. 2004) present significant barriers to implementing prescribed fires in many areas (Stephens and Ruth 2005), making thinning treatments often preferred in the wildland-urban interface (Kane et al. 2010).

Prescribed fire in combination with thinning have been shown to be most effective at reducing burn severity of subsequent wildfire (Agee and Skinner 2005; Finney et al. 2005; Stephens et al. 2009; Prichard et al. 2010; Hudak et al. 2011b; Kalies and Yocom Kent 2016). However, treatment longevity and effectiveness vary according to many factors. Stephens et al. (2012a) found that thinning followed by prescribed fire in a mixed conifer forest in Sierra Nevada was the most effective at reducing fire hazards (flame length and torching probability) for at least seven years post treatments, although they suggest that timing prescribed fire treatments 10 years post thinning treatments will potentially increase treatment effectiveness by 15 to 20 years. Prichard et al. (2010) found that thinning treatments in combination with prescribed burning in a mixed conifer forest was the most effective at reducing tree mortality during the Tripod Complex fires compared to no treatment and thinning alone. Fulé et al. (2005), though, found that thinning and burning treatments in a ponderosa pine- and Gamble oak (Quercus gambelii Nutt.)-dominant forest had minor effects on fuel loads five years post treatments. Thus, each ecosystem and site may have varied treatment longevity and effectiveness (Fulé et al. 2005; Fulé et al. 2007; Battaglia et al. 2008; Vaillant et al. 2009; Stephens et al. 2012a; Tinkham et al. 2016).

A common way to assess burn severity across landscapes is by using the Normalized Burn Ratio (NBR), a remotely sensed index sensitive to vegetation, soil, and char reflectance (Key and Benson 2006; Hudak et al. 2007). Subtracting the NBR value of a post-fire satellite image from a pre-fire satellite image provides the differenced NBR (dNBR), widely regarded as a useful indicator of burn severity (van Wagtendonk et al. 2004; 
Key and Benson 2006). Prior studies have found that dNBR is more influenced by tree canopy (where present) than by ground conditions, typically defining high burn severity as overstory consumption by fire (Hudak et al. 2007; Lentile et al. 2009).

The increase in large wildfire frequency and area burned at high severity (Westerling et al. 2006; Littell et al. 2009; Abatzoglou and Williams 2016), as well as the cost invested in fuel reduction treatments (Gorte 2013), has prompted examination into the effectiveness of thinning at reducing burn severity (Graham et al. 1999; Fulé et al. 2007; Bartuszevige and Kennedy 2009; Prichard et al. 2010; Tinkham et al. 2016). However, relatively few studies have investigated both short- and long-term ecological effects of pre-wildfire treatments on burn severity, understory vegetation recovery, and fuel accumulation after wildfires (Fulé et al. 2005; Hudak et al. 2011b; Stephens et al. 2012a). Understanding vegetation responses and fuel accumulations in response to burn severity post wildfire will assist land managers in prioritizing long-term fuel and fire management objectives. Therefore, our objectives were to (1) determine if pre-wildfire treatments lower burn severity (one-year post-fire $\mathrm{dNBR}$ ); (2) evaluate relationships between oneyear post-fire dNBR, years since treatment, and fieldmeasured biophysical attributes one and nine years post fire; (3) compare treatment and burn severity effects on field-measured biophysical attributes to better understand interactions between treatment and severity; and (4) assess changes over time by comparing biophysical attributes measured in year one and re-measured in year nine post fire across the Egley Fire Complex. For this study, we considered fuel treatments to be any event that modified or reduced woody fuels, including events conducted for the primary purpose of mitigating fire risk (e.g., pre-commercial thinning, pile and burn, prescribed fire) and events that modifying woody fuels as a byproduct (e.g., previous wildfires, commercial harvests).

\section{Methods}

\section{Study area}

The study area was within the Malheur National Forest, approximately $55 \mathrm{~km}$ northwest of Burns, Oregon, USA $\left(43.880556^{\circ},-119.640000^{\circ}\right)$. The Malheur National Forest occupies 688000 ha in the Blue Mountains of eastern Oregon and includes high desert grasslands, sagebrush (Artemisia spp. L.) steppe and western juniper (Juniperus occidentalis Hook.) woodlands, ponderosa pine forests, and mixed conifer forests. Our study focused on the southern ponderosa pine forests of the Malheur National Forest. Mean high temperature in the growing season (May through August) is $26{ }^{\circ} \mathrm{C}$ and the mean low temperature in winter (November through February) is $-8^{\circ} \mathrm{C}$. Mean annual precipitation is $279 \mathrm{~mm}$ (US Climate Data
2019). Elevation of our study sites ranged from $1506 \mathrm{~m}$ to $1755 \mathrm{~m}$ above sea level. Common grass species included needlegrass (Achnatherum spp. P. Beauv.), squirreltail (Elymus elymoides [Raf.] Swezey), and Sandberg bluegrass (Poa secunda J. Presl). Forb species included common yarrow (Achillea millefolium L.), blue-eyed Mary (Collinsia spp. Nutt.), and willowherb (Epilobium spp. L.). Invasive species included cheatgrass (Bromus tectorum L.), Canadian thistle (Cirsium arvense [L.] Scop.), and bull thistle (C. vulgare [Savi] Ten.). Snowbrush ceanothus (Ceanothus velutinus Douglas ex Hook.), creeping barberry (Mahonia repens [Lindl.] G. Don), and antelope bitterbrush (Purshia tridentata [Pursh] DC.) were the most common shrubs within the study area.

The Egley Fire Complex, composed of three lightning-ignited fires, burned approximately 56802 ha (Fig. 1) from 7 to 21 July 2007 under abnormally low precipitation and high temperatures for the area: total precipitation was $0.25 \mathrm{~mm}$ (29-year July normal precipitation $=10 \mathrm{~mm}$ ), the average high temperature was $34{ }^{\circ} \mathrm{C}$ (29-year July normal high temperature $=$ $30{ }^{\circ} \mathrm{C}$ ), and the average low temperature was $11{ }^{\circ} \mathrm{C}$ (29-year July normal low temperature $=8{ }^{\circ} \mathrm{C}$ ) (US Climate Data 2019). Prior to the Egley Fire Complex, the Malheur National Forest had implemented vegetation and fuel treatments for vegetation management and wildfire protection objectives beginning in 1985, with treatment units recorded as polygons in a Geographic Information System (GIS). Pre-fire silvicultural or fuel reduction treatments within the Egley Fire Complex perimeter included commercial harvests (7280 ha), pre-commercial thinning (6855 ha), slash and pile burns (6853 ha), and understory prescribed burns (1566 ha). Of the 42459 ha of Malheur National Forest lands that burned in the Egley Fire Complex, 19233 ha (45.3\%) had received some form of harvest, pre-commercial thinning, fuel, or fire treatment over the preceding 22 years. dating back to 1985 (Fig. 1a). Treatment units often had multiple entries. For instance, 668 of the 1041 treatment units intersected by the Egley Fire Complex had been commercially harvested, thinned, and had slash piles burned, as part of a silvicultural management system. Given the complexity imposed by multiple and interacting entries over a long range of years, we did not attempt to quantify separate effects of treatment types, but simply lumped together all lands within treatment units as "treated" to compare with untreated lands in our analysis. Three prior wildfires were also categorized as fuel treatments: the 1990 Squaw Flat Fire (540 ha), the 1990 Buck Springs Fire (8485 ha), and the 1990 Pine Springs Basin Fire (28 790 ha, Fig. 1a), which had previously burned on Malheur National Forest lands. 

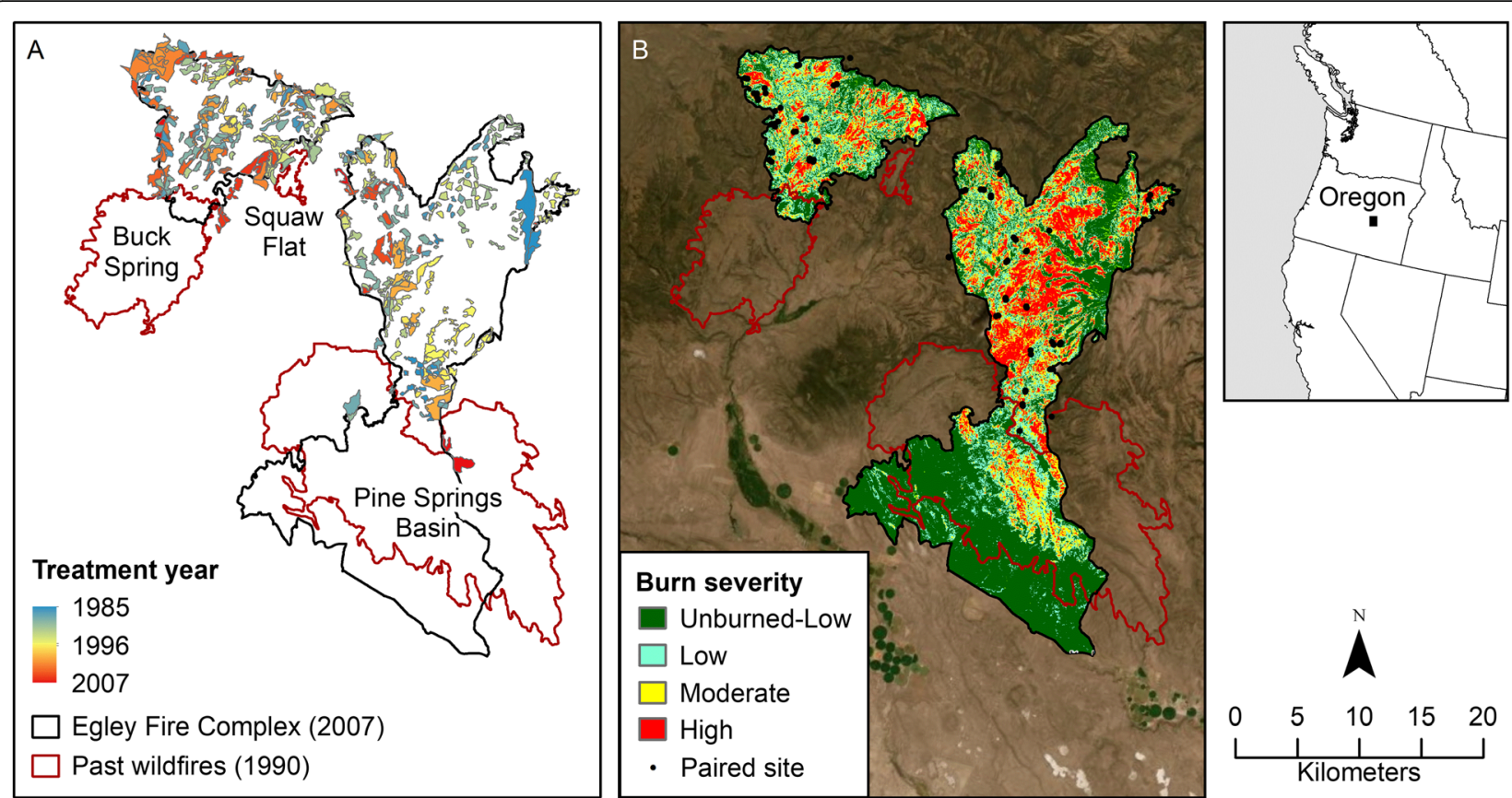

Fig. 1 Egley Fire Complex (2007) located in eastern Oregon, USA, showing (A) areas that had been treated pre-fire within the fire perimeter, (B) distribution of 35 paired field sites overlaid on the classified differenced Normalized Burn Ratio (dNBR) burn severity map (www.mtbs.gov), and (C) location of study area in Oregon, USA

\section{Field methods}

Field sites were monumented and first characterized in the summer of 2008 (one year post fire) and then remeasured in 2016 (nine years post fire). Field procedures are similar to those described by Hudak et al. (2011b). Each site consisted of a central plot and four additional quadrats situated orthogonally $30 \mathrm{~m}$ from the center plot and oriented to the prevailing slope to represent a cluster of three to five Landsat pixels (Fig. 2). Field sites were established from May to July 2008, prior to the availability of the Monitoring Trends in Burn Severity (MTBS) classification of burn severity. Therefore, a rapid response, Burn Area Remote Classification (BARC) map based on immediate post-fire dNBR values (Parsons and Orlemann 2002) was used as a guide to distribute field sites along the burn severity gradient. In the immediate

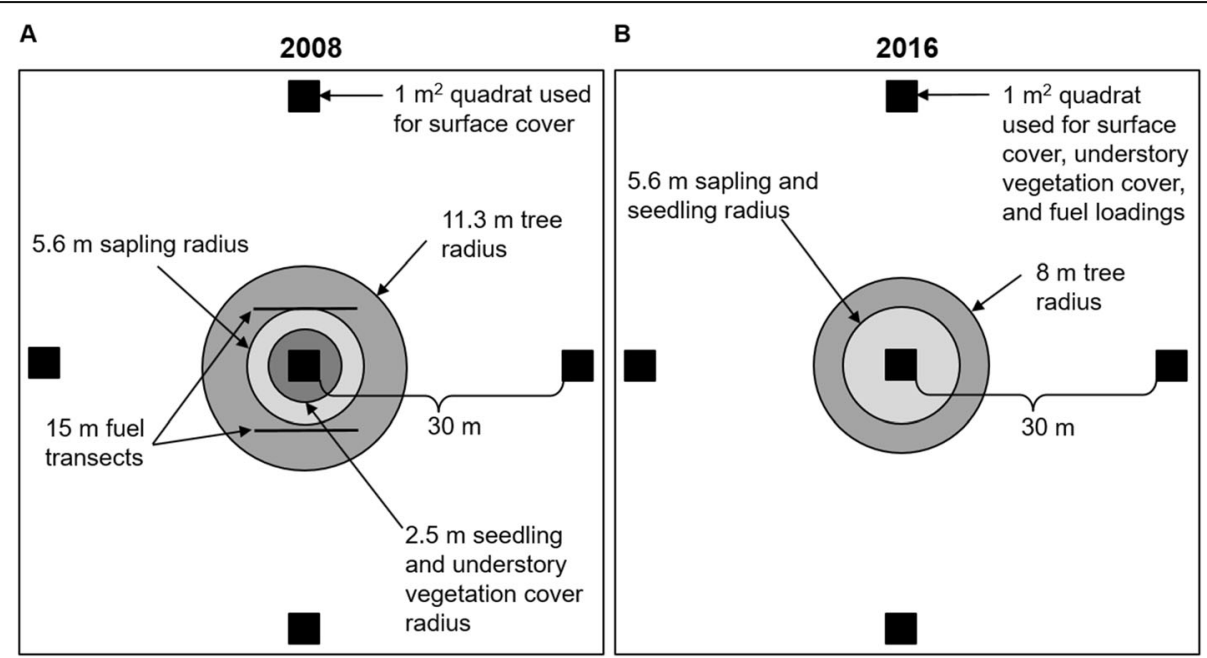

Fig. 2 Field site layout (not drawn to scale) used at field sampling sites after the 2007 Egley Fire Complex, eastern Oregon, USA, surveyed in the summers of (A) 2008, and (B) 2016 (Hudak et al. 2011b) 
post-fire BARC map, low burn severity corresponds to predominantly green (live) tree crowns, moderate burn severity corresponds to predominantly brown (scorched) tree crowns, and high burn severity corresponds to predominantly black (charred) tree crowns (Hudak et al. 2011a). Paired treated-untreated sites $(n=35$ each) were distributed across the burn severity gradient at locations guided by four criteria: (1) field assessment of burn severity; (2) year of final treatment to distribute sites across the range of time since treatment; (3) adjacency of treatment units to untreated sites with similar topographic slope, aspect, and older tree (pre-treatment) age structure (between 90 and $500 \mathrm{~m}$ apart); and (4) proximity to a navigable road. Zonal statistics in GIS were used to ensure minimal differences in elevation and slope between untreated (elevation: $1558 \pm 74.8 \mathrm{~m}$; slope: $7 \pm 5.7^{\circ}$ ) and treated (elevation: $1591 \pm 70.5 \mathrm{~m}$; slope: $7 \pm 5.9^{\circ}$ ) polygons.

At each site, overstory components (tree canopy cover, tree diameter at breast height, and tree density) and understory components (sapling and seedling density, surface cover, functional group understory species cover, and woody fuel loads) were measured. Tree canopy cover was estimated using a convex spherical densiometer facing the four cardinal directions around each plot. Tree density and basal area were measured at the center of the field site within a fixed radius of $11.3 \mathrm{~m}$ (0.04 ha) in 2008 or $8 \mathrm{~m}$ (0.02 ha) in 2016. Diameter at breast height (DBH, 1.37 $\mathrm{m}$ ), status (live or dead), and species were recorded for each tree greater than $10 \mathrm{~cm}$ DBH.

Seedlings and sapling density (stems $\mathrm{ha}^{-1}$ ) were used to estimate tree regeneration. All conifer saplings and seedlings taller than $5 \mathrm{~cm}$ were tallied by species and status (live and dead) recorded in circular plots. Saplings were tallied within a $5.6 \mathrm{~m}$ radius $(0.01 \mathrm{ha})$ for both sample years; seedlings in 2008 were tallied within a 2.5 $\mathrm{m}$ radius $(0.002 \mathrm{ha})$, whereas seedlings in 2016 were tallied within a $5.6 \mathrm{~m}$ radius. Saplings were defined as taller than breast height and DBH less than $10 \mathrm{~cm}$, whereas conifers shorter than breast height were considered seedlings.

Percent cover of understory components was estimated within five $1 \mathrm{~m}^{2}$ quadrats at each site (Fig. 2). Surface cover components included percent green vegetation, organic nonphotosynthetic (dead or dormant) vegetation (NPV), mineral soil, rock, and the proportion of surface covers that had residual blackened carbon (char). Examples of NPV include woody debris, senesced grass, tree bark, litter, and duff. Due to low vegetation surface cover in 2008 , understory vegetation cover was identified to functional groups and percent cover was estimated only within the $2.5 \mathrm{~m}$ radius understory center plot (Fig. 2). Functional groups included shrub, graminoid, forb, invasive species of interest (cheatgrass, and Canadian and bull thistles), and moss-lichen-fungi.
In 2008, fuel loads (biomass in $\mathrm{Mg} \mathrm{ha}^{-1}$ ) were estimated (Brown 1974) for coarse woody debris (CWD; 1000-hour fuels), or woody fuels greater than $7.6 \mathrm{~cm}$ in diameter, along two $15 \mathrm{~m}$ transects laid along the slope on the upslope or downslope sides of the $5.6 \mathrm{~m}$ radius plot (Fig. 2). Fuel loads of fine woody debris (FWD) in 2008 were estimated for woody fuels between 0 and 0.64 $\mathrm{cm}$ in diameter (1-hour fuels), 0.64 and $2.54 \mathrm{~cm}$ in diameter (10-hour fuels), and 2.54 and $7.6 \mathrm{~cm}$ in diameter (100-hour fuels) within the central $2 \mathrm{~m}$ section of each $15 \mathrm{~m}$ transect and were converted to fuel loads $\left(\mathrm{Mg} \mathrm{ha}^{-1}\right)$ per Woodall and Monleon (2006) for ponderosa pine. In 2016, the photoload fuel sampling technique (Keane and Dickinson 2007) was used to estimate CWD and each FWD woody fuel size class (biomass in $\mathrm{Mg} \mathrm{ha}^{-1}$ ) to speed field sampling. Fine woody debris fuel loads were estimated within the $1 \mathrm{~m}^{2}$ quadrats at each plot and averaged to the site level, while CWD fuel loads were estimated within a $5.6 \mathrm{~m}$ radius around the center plot. Litter and duff depths were measured with a ruler to the nearest $1 \mathrm{~mm}$ at each $1 \mathrm{~m}^{2}$ plot in both 2008 and 2016 and then used to calculate litter and duff fuel load $\left(\mathrm{Mg} \mathrm{ha}^{-1}\right.$; Stephens et al. 2004).

\section{Remote sensing data}

One-year post-fire dNBR values (burn severity index) were obtained from the Monitoring Trends in Burn Severity (MTBS) program (Eidenshink et al. 2007). For the Egley Fire Complex, MTBS used Landsat 5 TM image from 18 July 2006 for the pre-fire image and an image from 7 July 2008 for the post-fire image to calculate dNBR. The MTBS thematic burn severity product binned the dNBR image into five thresholds: no data (-970), increased greenness $(-150)$, low severity (100), moderate severity (215), and high severity (385) (Eidenshink et al. 2007).

In addition to dNBR, LandTrendr (Landsat-based Detection of Trends in Disturbance and Recovery; Kennedy et al. 2010) implemented in Google Earth Engine (GEE; Gorelick et al. 2017; Kennedy et al. 2018) was used to observe vegetation change (NBR) after the Egley Fire Complex. Landsat image composites (30 m spatial resolution) of summer NBR from 1984 through 2016 were created across the Egley Fire Complex extent. NBR image composites were then input into the LandTrendr algorithm, which modeled pixel-wise trends and trajectories while eliminating noise, resulting in an annual time series of Landsat NBR images fitted to LandTrendr segments. GEE was used to create NBR composites and implement the LandTrendr algorithm (Kennedy et al. 2018). NBR time series at site locations were extracted for vegetation recovery analysis. To determine when NBR recovered to unburned-low levels at plot locations, we tested whether NBR distributions varied by burn severity with Student's $t$-tests for each year post fire. 


\section{Statistical analysis}

Variables collected at all five quadrat locations per field site were aggregated to the site level. Due to non-normal distributions, a non-parametric blocked multi-response permutation procedure (MRBP) with Euclidean distance measure (PC-ORD v.7; McCune and Mefford 2016) was used to determine differences in burn severity (one-year post-fire dNBR) between treated and untreated sites (blocked by treatment; objective 1). An MRBP was also used to determine changes in biophysical attributes (i.e., tree canopy cover, understory green vegetation cover, total char cover, and total fuel loads) between 2008 and 2016 (blocked by year; objective 4). An MRBP provides the chance-corrected within-group agreement $(A)$, which is the likelihood of homogeneity within a group that occurs by chance. If $A=1$, all variables are homogenous within a group; whereas, if $A<0$, there is more heterogeneity within a group than expected by chance. If $A=$ 0 , then heterogeneity within a group equals what was expected by chance (McCune and Grace 2002).

To test for interacting effects of one-year post-fire $\mathrm{dNBR}$ and time since treatment on biophysical attributes (objective 2), linear regression models predicting select biophysical attributes were fit as a function of one-year post-fire dNBR, time since treatment (years), and their interaction ( $\mathrm{R}$ Core Team 2013). Untreated sites were considered as having been treated in 1910, when widespread wildfires occurred, and thus as 97 years since treatment. Linear regression models were fit using the Global Validation of linear models' assumptions (gvlma) package in R (Peña and Slate 2006). Data that failed normality and heteroscedasticity assumptions were modeled either by using beta regression models with additional Fisher scoring iterations if data were proportions (Cribari-Neto and Zeileis 2010), or by using generalized models, using Gamma family distributions (Nelder and Wedderburn 1972), if data were continuous.

Due to an insufficient number of treated sites that burned at high severity $(n=3)$, we grouped sites by treatment status (treated or untreated) and burn severity (unburned-low or moderate-high) to evaluate the combined effects of treatment and burn severity (one year post fire) on biophysical attributes (objective 3). The 4class dNBR burn severity classification (unburned, low, moderate, high) was simplified to two classes to differentiate sites with or without stand-replacing fire (dNBR values 61 to 250 for low burn severity and 251 to 753 for high burn severity). The classification resulted in four groups: treated sites that were unburned or burned at low severity (T-low; $n=30$ ), treated sites that burned at moderate or high severity (T-high; $n=5$ ), untreated sites that were unburned or burned at low severity (U-low; $n$ =11), and untreated sites that burned at moderate or high severity (U-high; $n=24$ ). A permutation ANOVA with "Exact" permutations that generate all permutations of $\mathrm{Y}$ was used to test significant interactions of all variables between treatment and severity, which were non-normally distributed, and Tukey's honestly significant difference (Tukey HSD) multiple comparisons tests were used for post-hoc pairwise comparisons ( $\mathrm{R}$ Core Team 2013).

\section{Results}

Landscape-level summary of treatment effects on burn severity (objective 1)

The MTBS-based dNBR classification of burn severity summarized across the entire Egley Fire Complex showed that $26.7 \%$ (6085 ha) of untreated lands (23 226 ha) burned with high severity, whereas only $12.9 \%$ (2150 ha) of treated lands (19 233 ha) burned with high severity (Fig. 3a and b). Thus, untreated lands were twice as likely as treated lands to have burned with high severity. The complete landscape analysis of the Egley Fire Complex showed that the proportion of treated areas that burned at high severity increased with time since treatment (i.e., treated areas $>10$ years old had a high burn severity proportion more similar to that of untreated areas, than did more recently treated areas $<10$ years old; Fig. $3 b$ ).

\section{Site level analysis of remotely sensed data (objectives 1 and 2)}

In accordance with the landscape analysis, a Student's $t$ test was run on the landscape variables elevation, slope, and distance to road between treated and untreated sites (all $P>0.05$ ), demonstrating minimal landscape differences between treated and untreated sites. However, one-year post-fire burn severity (dNBR) was significantly lower in treated sites than in their paired untreated sites (MRBP $P<0.001, A=0.27$ ). LandTrendr-derived trajectories of NBR decreased sharply following the fire and gradually increased over time as vegetation recovered. Treated sites that burned at high severity had recovered to unburned-low NBR levels within four years post fire (Student's $t$-test, $P=0.052$ in 2010, $P=0.271$ in 2011), whereas untreated sites that burned at moderate or high severity had still not recovered to unburned-low NBR levels nine years post fire (Student's $t$-test, $P=0.002$; Fig. 4a and b). Linear regression models showed that total (live and dead) tree canopy cover also increased with time since treatment in 2008 (Table 1). The interaction between one-year post-fire dNBR and time since treatment was also a significant predictor of 2008 tree canopy cover; as dNBR and time since treatment increased, tree canopy cover decreased (Table 1). Tree canopy cover measured in 2016 was lower at sites with higher one-year post-fire dNBR values; in other words, sites that burned at high severity still had lower tree canopy cover nine years post fire. Understory green 


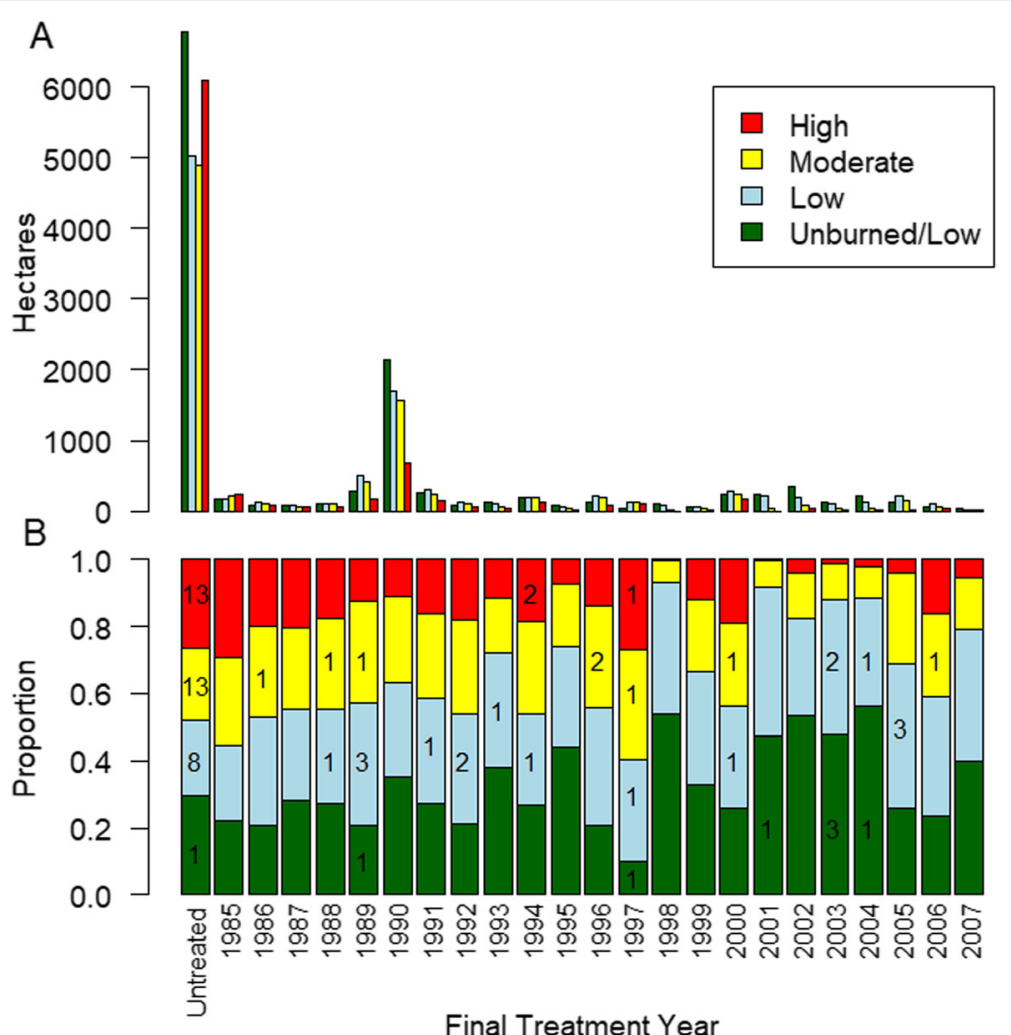

Fig. 3 Burn severity class (A) hectares and (B) proportions summarized from differenced Normalized Burn Ratio (dNBR) values mapped by Monitoring Trends in Burn Severity (MTBS) across the 2007 Egley Fire Complex, eastern Oregon, USA, versus time since final fuels treatment. Numbers within columns in (B) indicate number of field sites sampled in each treatment year across Monitoring Trends in Burn Severity (MTBS) burn severity classes, which were unavailable when the sites were installed in 2008 (www.mtbs.gov)

vegetation cover significantly decreased with $\mathrm{dNBR}$ in 2008 but significantly, though slightly, increased as dNBR and time since treatment increased. In 2016, understory green vegetation cover increased as one-year post-fire dNBR increased. Total char increased with one-year post-fire dNBR both in 2008 and 2016, expectedly. Total fuel loads were not significantly predicted by one-year post-fire $\mathrm{dNBR}$, time since treatment, or the interaction between the two in 2008 or in 2016. It is important to note that, although most linear models were significant, they had relatively low coefficients of determination $\left(R^{2}\right)$, therefore much of the variability is not being accounted for by the models (Table 1 ).

\section{Treatment and burn severity effects on biophysical attributes (objective 3 )}

All live trees, saplings, and seedlings sampled in both 2008 and 2016 were ponderosa pine, apart from two juniper saplings recorded in 2008. Tree canopy cover in 2008 was affected by severity and the interaction between treatment and severity (both $P \leq 0.034$, both $F \geq 4.7$ ), with untreated sites that burned at low severity $(53.2 \pm 4.3 \%$ [mean $\pm \mathrm{SE}])$ having significantly higher canopy cover than treated sites that also burned at low severity $(38.6 \pm 1.9 \%)$ or untreated sites that burned at high severity $(36.0 \pm 2.6 \%$; both $P \leq$ 0.005). Tree canopy cover measured in 2016 was only affected by severity $(P<0.001, F=38.0)$, whereby sites that burned at low severity had higher canopy cover (treated: $35.1 \pm 3.4 \%$, untreated: $50.5 \pm 6.4 \%$ ) than sites that burned at high severity (treated: $9.8 \pm 6.0 \%$, untreated: $13.0 \pm 2.6 \%$ ), regardless of treatment (all $P \leq 0.014$ ). Live tree basal area in 2008 did not differ between treatments or severity, but it had been affected by severity when measured in $2016(P<0.001, \mathrm{~F}=13.7)$. Sites that burned at low severity had more live basal area (treated: $12.4 \pm 2.1 \mathrm{~m}^{2} \mathrm{ha}^{-1}$, untreated: $20.6 \pm 1.1 \mathrm{~m}^{2} \mathrm{ha}^{-1}$ ) than untreated sites that burned at high severity (both $P \leq 0.005,1.6 \pm 5.3 \mathrm{~m}^{2} \mathrm{ha}^{-1}$ ). Dead tree basal area in 2008 was also influenced by severity $(P=0.008, F=7.4)$; dead tree basal area was higher in untreated sites that burned at high severity $(2.2 \pm$ $0.1 \mathrm{~m}^{2} \mathrm{ha}^{-1}$ ) than in sites that burned at low severity (treated: $1.0 \pm 0.3 \mathrm{~m}^{2} \mathrm{ha}^{-1}$, untreated: $0.3 \pm 0.4 \mathrm{~m}^{2} \mathrm{ha}^{-1}$, both $P \leq 0.035$ ).

Live tree density in 2008 was affected by severity and the interaction between treatment and severity (both $P \leq 0.004$, both $F \geq 8.6$ ), and in 2016 , live tree density was affected by 

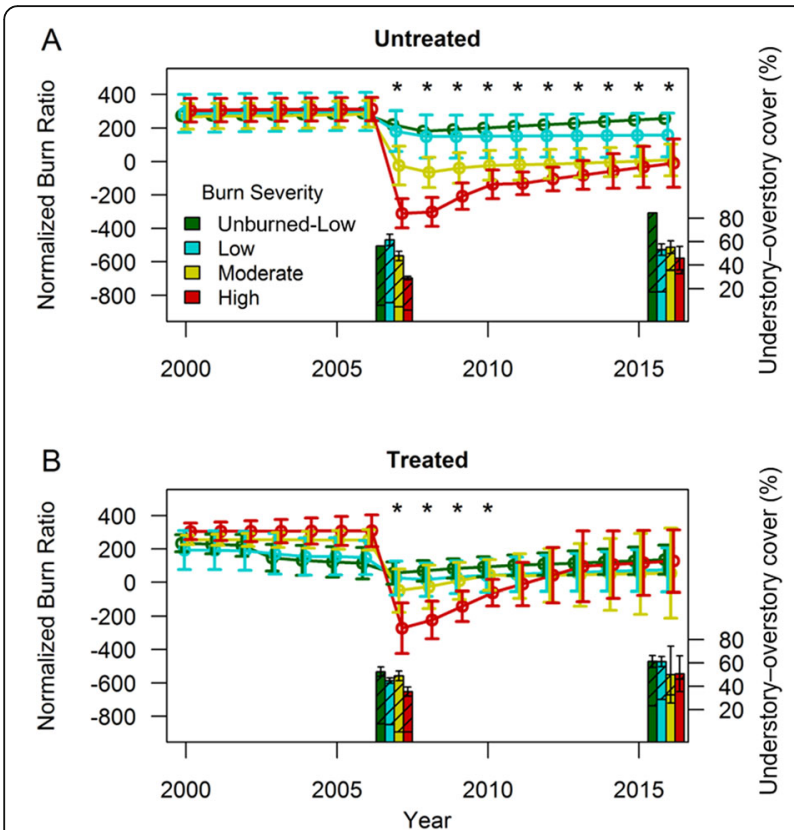

Fig. 4 LandTrendr time series of the Normalized Burn Ratio (NBR) values for the Egley Fire Complex (2007), eastern Oregon, USA, area from 2000 to 2016 for both (A) untreated and (B) treated sites. Column graphs demonstrate percent canopy cover including overstory tree cover (hatched columns) and understory green vegetation cover (unhatched columns). Standard error bars are additive for both cover components. Note that there was only one untreated-unburned-low site according to the Monitoring Trend in Burn Severity (MTBS) classification (www.mtbs.gov), hence there is no error bar. Significance of Student's t-tests between severity groups shown above each respective year: ${ }^{*}, P \leq 0.05$

severity, treatment, and their interaction (all $P \leq 0.008$, all $F$ $\geq 8.8$ ); untreated sites that burned at low severity had higher live tree density than all other sites in both years (Fig. 5). Dead tree density in 2008 was only affected by severity $(P<0.001, F=46.2)$, being significantly higher in high-severity burned sites than low-severity burned sites, regardless of treatment $(P<0.001$; Fig. 5a). Live sapling density in 2008 did not vary between treatment and severity, but in 2016 it was strongly influenced by treatment, severity, and the interaction between the two (all $P \leq 0.016$, all $F \geq 7.3$ ), being highest in untreated sites that burned at low severity (Fig. 5). Dead sapling density in 2008 was only affected by treatment $(P<0.001$, $F=17.0$ ), being higher in untreated sites than treated, regardless of severity $(P=0.002$, Fig. $5 \mathrm{a})$. Dead sapling density measured in 2016 was influenced by treatment, severity, and their interaction (all $P \leq 0.02$, all $F \geq 5.6$ ), being highest in untreated sites that burned at low severity (Fig. 5b). Only dead seedling density in 2016 was influenced by severity $(P=0.014, F=6.4)$. However, Tukey multiple comparisons tests showed no differences in live or dead seedling density by treatment or severity in 2008 or 2016 (Fig. 5).
Combined pre-fire treatment and severity effects on ground surface cover fractions varied between years. Understory green vegetation cover in 2008 was only affected by severity $(P<0.001, F=12.0)$, being significantly higher in low-severity burn sites than highseverity burn sites, regardless of treatment (Fig. 6a). In 2016, understory green vegetation cover was affected by treatment and severity (both $P \leq 0.025$, both $F \geq 5.2$ ); however, the trend was reversed from 2008: sites that burned with low severity had significantly lower green vegetation cover than treated sites that burned at high severity (Fig. 6b). Non-photosynthetic vegetation (NPV) in 2008 and 2016 was affected by treatment and severity (in 2008 , both $P \leq 0.001$, both $F \geq 11.6$; in 2016 , both $P$ $\leq 0.028$, both $F \geq 5.0$ ), being significantly reduced by treatment and high severity with untreated sites that burned at low severity having the highest NPV (Fig. 6a). Both treatments and severity affected soil and rock cover in 2008 (both $P<0.001$, both $F \geq 12.8$ ), with treatments and high-severity burns causing more soil and rock exposure, although not detectable in 2016 (Fig. 6). Total char cover in both sample years was only affected by severity (both $P<0.001, F \geq 7.7$ ). In 2008, total char cover was higher in sites that burned at high severity than low severity regardless of treatment (Fig. 6a) and, in 2016, untreated sites that burned at high severity had more char than both treated and untreated sites that burned at low severity (Fig. 6b).

Cover of understory vegetation functional groups were not significantly affected by treatment or severity in 2008 (see Table 2 for statistics). However, when measured in 2016, shrub and graminoid cover response differed by treatment and severity; treated sites that burned at high severity had higher shrub cover than sites that burned with low severity, whereas graminoid cover was higher in sites that were untreated and burned with high severity than sites that burned at low severity (Table 2). Forb and invasive species cover measured in 2016 were both affected by burn severity: forbs were higher in untreated sites that burned with high severity than in untreated sites that burned with low severity, and invasive species cover was higher in untreated sites that burned with high severity than in treated sites that burned with low severity (Table 2). Moss-lichen-fungi cover significantly decreased as burn severity increased, although it was unaffected by treatment (Table 2).

Total fuel loads (1000-hour, 100-hour, 10-hour, 1-hour, litter and duff) were not affected by either treatment or severity when measured in 2008 or 2016 . However, CWD in 2016 was affected by severity and the interaction between treatment and severity (both $P \leq 0.038, F \geq 4.4$ ), being higher in untreated sites that burned with high severity than in treated or untreated sites that burned with low severity (both $P \leq 0.007$; Fig. 7b). Fine woody debris in 
Table 1 Regression models predicting percent tree canopy cover, understory green vegetation cover, total char cover, and total fuel loads (Mg ha ${ }^{-1}$ ) measured after the 2007 Egley Fire Complex, eastern Oregon, USA, in 2008 and 2016 as a function of one-year postfire $d N B R$, time since treatment (Years), and the interaction of one-year post-fire dNBR and time since treatment. Linear regression models were used for 2008 tree canopy cover, 2008 total char, and 2016 understory green vegetation cover and the degrees of freedom were 66 for all models. Beta regression models were used for 2008 understory green vegetation cover, 2016 tree canopy cover, and 2016 total char cover; number of iterations were $34+4$ (Fisher scoring), $12+2$, and $23+3$, respectively. Generalized linear regressions with Gamma family distributions were used for both 2008 and 2016 total fuel loads. Boldface denotes significance at the $95 \%$ confidence interval, and SE denotes standard error of the estimate, $t=t$-statistic (for linear and generalized linear models), $z=$ Z-statistic (given for beta regression models), $\mathrm{E}=$ scientific notation (10 to the power of)

\begin{tabular}{|c|c|c|c|c|c|c|c|c|c|}
\hline & Predictor variables & 2008 & & & & 2016 & & & \\
\hline \multirow[t]{5}{*}{ Tree canopy cover (\%) } & & Estimate & SE & $t$ & $P$ & Estimate & SE & z & P \\
\hline & $d N B R$ & 0.008 & 0.016 & 0.491 & 0.625 & $-4.66 \mathrm{E}-03$ & $1.23 \mathrm{E}-03$ & -3.782 & $<0.001$ \\
\hline & Years & 0.245 & 0.062 & 3.932 & $<0.001$ & $7.70 \mathrm{E}-03$ & 4.01E-03 & 1.918 & 0.055 \\
\hline & $d N B R^{*}$ Years & -0.001 & 0.000 & -2.944 & 0.004 & $-8.90 \mathrm{E}-06$ & $1.51 \mathrm{E}-0.5$ & -0.589 & 0.556 \\
\hline & & \multicolumn{4}{|c|}{ Model: $F=8.6, P<\mathbf{0 . 0 0 1}, R^{2}=0.281$} & \multicolumn{4}{|c|}{ Model: $z=6.0, P<\mathbf{0 . 0 0 1}$, pseudo $R^{2}=0.63$} \\
\hline \multirow{5}{*}{$\begin{array}{l}\text { Understory green } \\
\text { vegetation cover (\%) }\end{array}$} & & Estimate & SE & z & P & Estimate & SE & $t$ & P \\
\hline & $\mathrm{dNBR}$ & -0.005 & 0.001 & -4.187 & $<0.001$ & 0.048 & 0.018 & 2.657 & $<0.001$ \\
\hline & Years & -0.007 & 0.004 & -1.731 & 0.084 & -0.034 & 0.068 & -0.491 & 0.625 \\
\hline & $d N B R^{*}$ Years & $3.652 \mathrm{E}-05$ & 0.000 & 2.376 & 0.018 & $-1.81 \mathrm{E}-04$ & 0.000 & -0.806 & 0.423 \\
\hline & & \multicolumn{4}{|c|}{ Model: $z=5.5, P<\mathbf{0 . 0 0 1}$, pseudo $R^{2}=0.44$} & \multicolumn{4}{|c|}{ Model: $F=5.3, P=\mathbf{0 . 0 0 3}, \mathrm{R}^{2}=0.193$} \\
\hline \multirow{5}{*}{$\begin{array}{l}\text { Total char } \\
\text { cover (\%) }\end{array}$} & & Estimate & SE & $t$ & $P$ & Estimate & SE & z & P \\
\hline & $d N B R$ & 0.083 & 0.023 & 3.635 & $<0.001$ & 0.003 & 0.001 & 2.849 & 0.004 \\
\hline & Years & 0.11 & 0.087 & 1.265 & 0.210 & 0.004 & 0.004 & 0.977 & 0.328 \\
\hline & $d N B R^{*}$ Years & $-3.65 \mathrm{E}-04$ & 0.000 & -1.271 & 0.208 & $-1.829 \mathrm{E}-06$ & 0.000 & -0.153 & 0.878 \\
\hline & & \multicolumn{4}{|c|}{ Model: $F=12.1, P<\mathbf{0 . 0 0 1}, R^{2}=0.356$} & \multicolumn{4}{|c|}{ Model: $z=5.5, P<\mathbf{0 . 0 0 1}$, pseudo $R^{2}=0.26$} \\
\hline \multirow{5}{*}{$\begin{array}{l}\text { Total fuel loads } \\
\left(\mathrm{Mg} \mathrm{ha}^{-1}\right)\end{array}$} & & Estimate & SE & $t$ & $P$ & Estimate & SE & $t$ & P \\
\hline & $d N B R$ & $9.284 \mathrm{E}-05$ & 0.000 & 0.618 & 0.539 & 3.786E-05 & 0.000 & 0.919 & 0.362 \\
\hline & Years & $9.186 \mathrm{E}-06$ & 0.000 & 0.022 & 0.982 & $1.243 \mathrm{E}-04$ & 0.000 & 1.022 & 0.310 \\
\hline & $d N B R^{*}$ Years & $-1.177 \mathrm{E}-06$ & 0.000 & -0.711 & 0.480 & $-8.221 \mathrm{E}-07$ & 0.000 & -1.824 & 0.073 \\
\hline & & \multicolumn{4}{|c|}{$\begin{array}{l}\text { Null deviance: } 82.234 \text { on } 68 \text { degrees of freedom, } \\
\text { Residual deviance: } 79.626 \text { on } 65 \text { degrees of } \\
\text { freedom }\end{array}$} & \multicolumn{4}{|c|}{$\begin{array}{l}\text { Null deviance: } 33.465 \text { on } 69 \text { degrees of freedom, } \\
\text { Residual deviance: } 27.429 \text { on } 66 \text { degrees of } \\
\text { freedom }\end{array}$} \\
\hline
\end{tabular}

2008 was similarly influenced by severity $(P=0.001, F=$ 11.6), being higher in untreated sites that burned with low severity than in treated sites that burned with high severity (both $P \leq 0.031$; Fig. 7a). Fine woody debris measured in 2016 was affected by severity and treatment (all $P \leq 0.034$, all $F \geq 7.3$ ); untreated sites that burned with low severity had higher FWD loads than all other sites (all $P \leq 0.040$; Fig. 7b).

\section{Changes over time (objective 4)}

All biophysical variables measured in 2008 significantly differed from variables measured in 2016 except for dead seedling density and duff (see Table 3 for statistics). Tree canopy cover and density were significantly reduced over time with fair within-group agreement, whereas tree basal area significantly increased over time, although within- group agreement was low (Table 3). Surface cover of green vegetation and NPV, cover of understory functional groups, and fuel loads (except 100-hour fuels) also increased significantly over time (Table 3), as would be expected nine years post fire. Soil and rock cover and char decreased from 2008 to 2016, as would be expected. Surface cover of all types, except NPV, had high within-group agreement $(A>0.3)$. According to McCune and Grace (2002), $A>0.3$ is fairly high in community ecology, indicating that the observed differences between time periods are ecologically significant, in addition to being statistically significant. Understory functional groups and fuels, however, had fairly low withingroup agreement, except for 1-hour fuels and litter, which both had high within-group agreement (Table 3), indicating high variability for functional groups and fuels measured among sites sampled in both 2008 and 2016. 


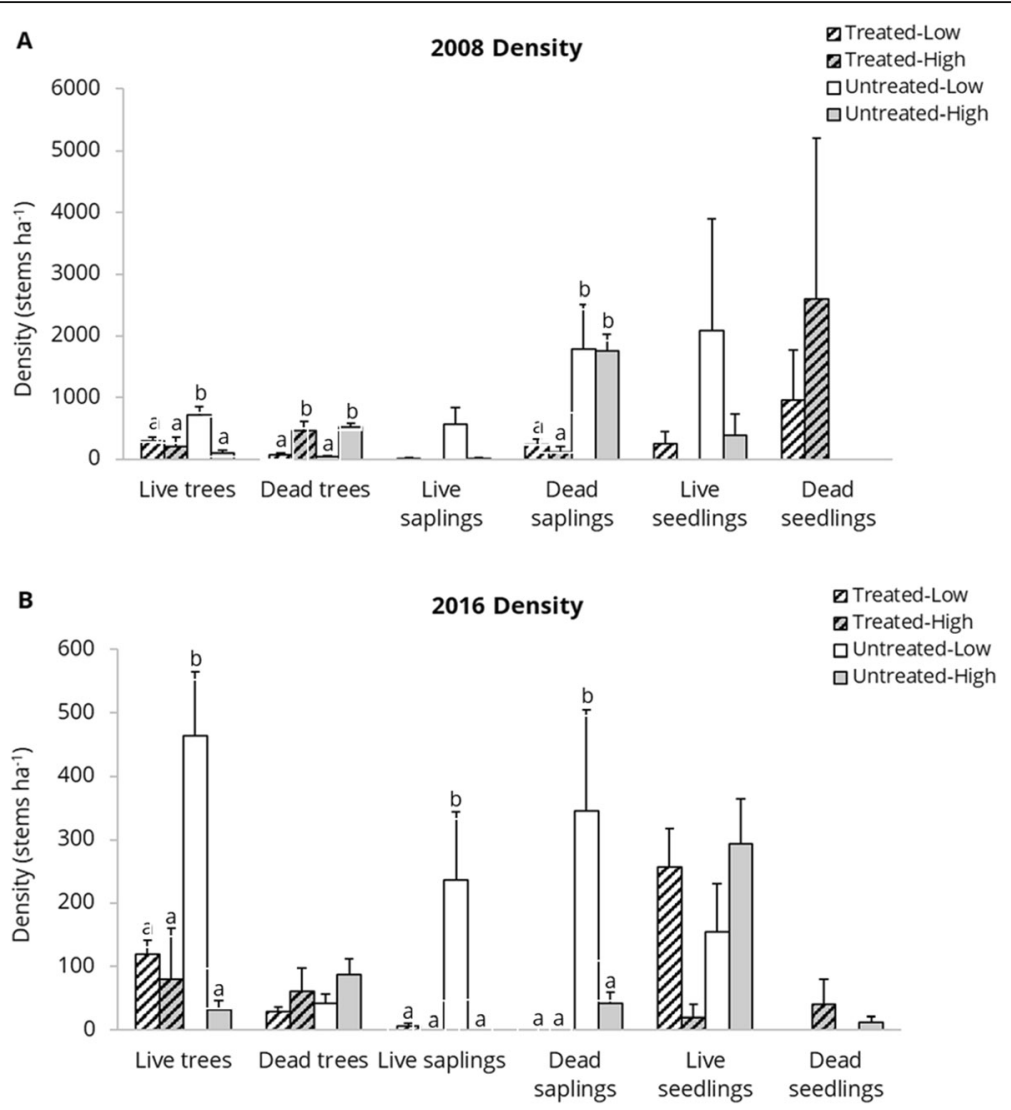

Fig. 5 Density (stems ha ${ }^{-1}$ ) of ponderosa pine trees, saplings, and seedlings estimated after the 2007 Egley Fire Complex, eastern Oregon, USA, in (A) 2008 and (B) 2016, contrasting treatment-severity groups. Letters shown above standard error bars denote significant Tukey multiple comparisons between treatment and severity groups, $P<0.05$. Note that (A) 2008 has a different scale than (B) 2016

\section{Discussion}

Our study found that commercial harvests, pre-commercial thinnings, pile and burns, and previous wildfires were effective fuel reduction treatments in that they reduced the burn severity of the Egley Fire Complex. Most treated sites burned at low severity, reflecting the results of previous research that found that pre-fire fuel reduction treatments in fire-suppressed dry ponderosa pine forests were effective at reducing burn severity (Agee and Skinner 2005; Stephens et al. 2009; Fulé et al. 2012). Burn severity effects over time were successfully observed by LandTrendr remote sensing analysis. Treated sites that burned at high severity recovered to unburned-low NBR levels within four years after fire, while untreated sites had not returned to pre-fire NBR levels even after nine years. Kennedy et al. (2010) also found that LandTrendr time series were effective at capturing disturbances and vegetation recovery in dry ponderosa pine forests in Washington and Oregon, USA. Using LandTrendr, pre- and post-disturbance vegetation trends can be consistently monitored on a landscape level through time with more detail than is commonly feasible with field monitoring crews. However, field monitoring crews are critical for both interpreting and validating remotely sensed data.
Biophysical attributes measured in 2008 and re-measured in 2016 were predicted by one-year post-fire dNBR. Similar to findings of prior studies (Hudak et al. 2007; Lentile et al. 2009), we documented a strong relationship between dNBR and tree canopy cover. Understory variables, except total fuel loads, were also predicted by dNBR, most notably total char cover. Lentile et al. (2009) found similar results after the 2000 Jasper Fire in the ponderosa pine-dominated Black Hills of South Dakota, USA. We documented that char cover was significantly predicted by the dNBR nine years post fire, although the coefficient of determination was relatively low. This reinforces Lentile et al.'s (2009) findings and indicates that char cover can still be found in burned areas nine years post fire, more notably in areas that burned at high severity, and thus can be used as an indicator of burn severity up to nine years post fire.

Agee and Skinner (2005) suggested that fuel treatments become less effective at reducing burn severity after 10 to 15 years. Most of the treated sites that we observed were treated between 1 to 21 years prior to the Egley Fire Complex, yet were still successful at reducing burn severity in the area compared to untreated sites. However, Prichard et al. (2010) found 


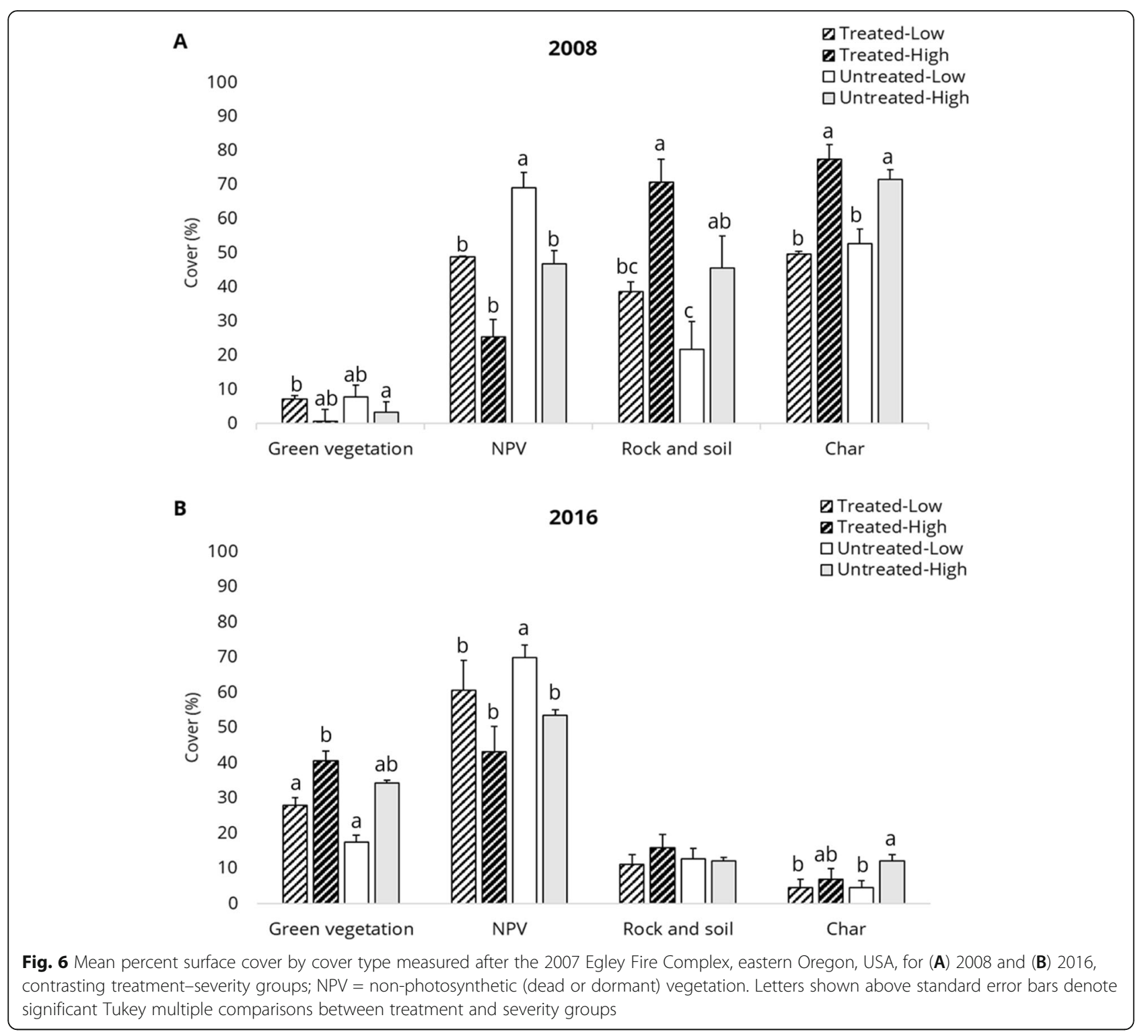

higher burn severity in ponderosa pine stands that had been recently thinned ( 15 years pre fire), but where surface fuels had not yet been treated, as did Hudak et al. (2011b) in cold mixed conifer forest stands thinned the previous year but with fuel piles remaining. This highlights the importance of surface fuel treatments in conjunction with thinning treatments. The success of fuel treatments at reducing high-severity fire in the Malheur National Forest might be because most of the treatment units intersected by the Egley Fire Complex (668 of 1041) had received multiple treatment entries, thus increasing treatment effectiveness.

Live and dead tree and sapling density were significantly affected by treatments but neither live nor dead tree basal area were significantly affected by treatments.
The lack of basal area trends is likely because precommercial thinning treatments usually remove smalldiameter trees, which contribute little to overall tree basal area when larger trees are present (Agee and Skinner 2005). Areas that burned at high severity, however, had lower live tree basal area in 2016 and higher dead tree basal area in 2008. The lack of differences by treatment and severity found in standing dead tree basal area and tree density in 2016 can be attributed to many dead trees in high-severity burn sites having fallen and become downed woody fuels. Passovoy and Fulé (2006) and Roccaforte et al. (2012) both found that snag density significantly decreased after three to four years post fire, whereas CWD biomass increased in ponderosa pine forests. 
Table 2 Permutation ANOVA and Tukey multiple comparison test results for treatment-severity interactions between surface covers measured after the 2007 Egley Fire Complex, eastern Oregon, USA, in 2008 and 2016. Treat = treatment (two factors: treated or untreated), Sev = severity (two factors: low or high), $T=$ treated, $U=$ untreated, $F=$ F-statistic, boldface denotes significance at the 95\% confidence level, and dashes (-) indicate no significant difference. Degrees of freedom for all permutation ANOVA tests were 1 for each predictor variable. Letters denote significant Tukey multiple comparisons (Tukey's honestly statistical difference [HSD]) between treatment and severity groups

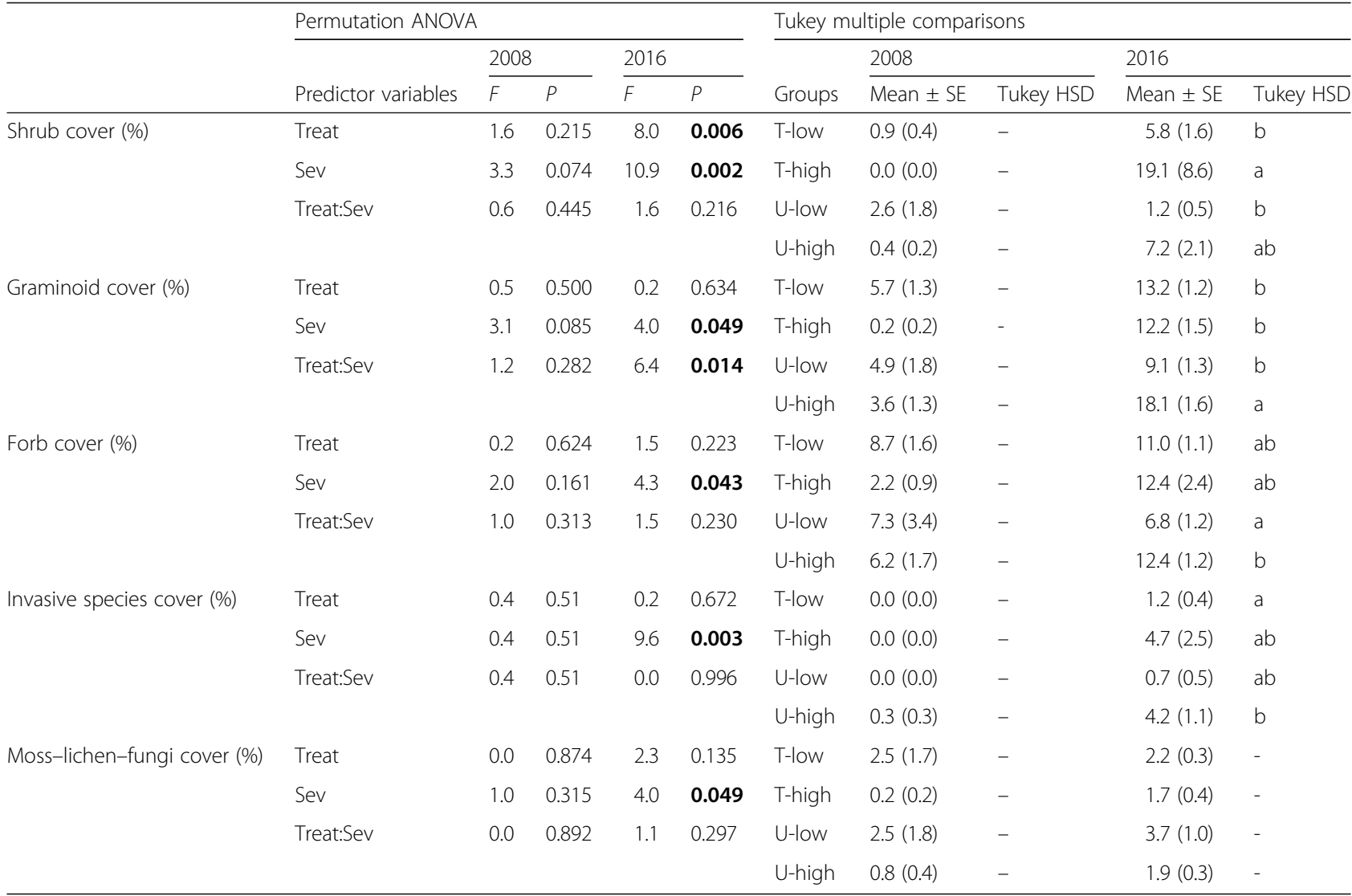

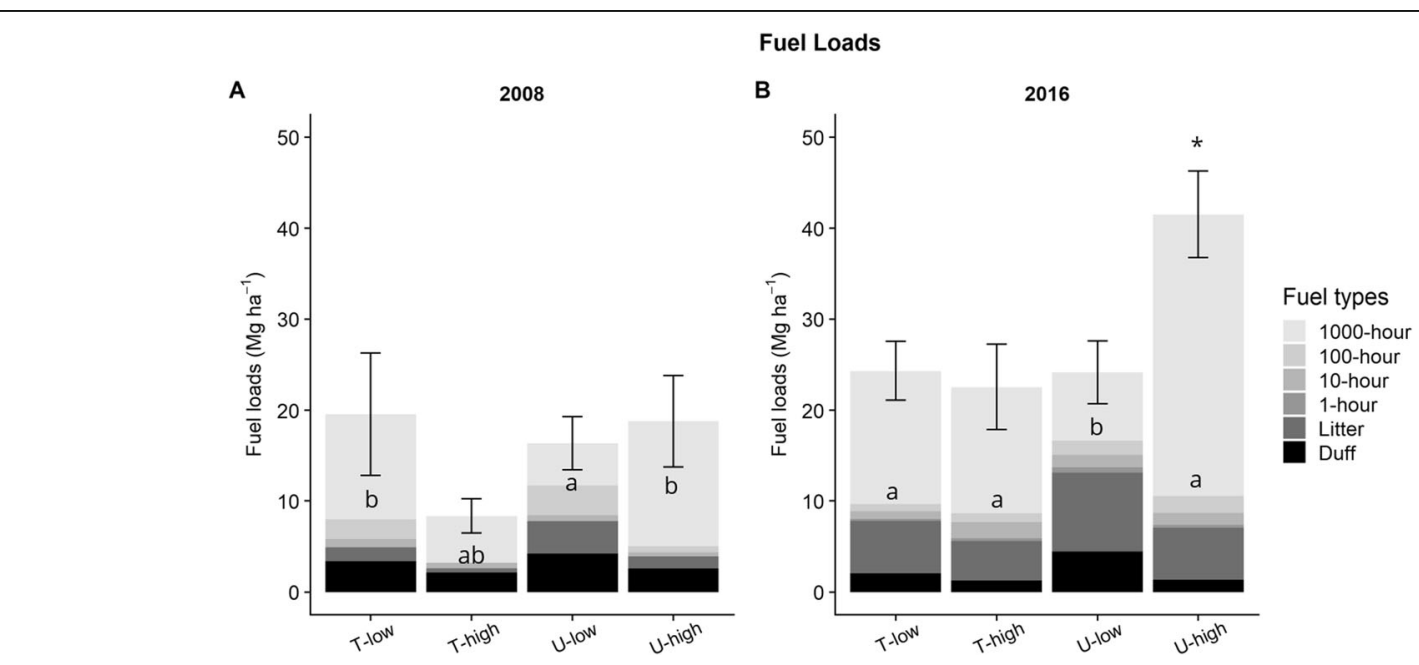

Fig. 7 Fuel loads $\left(\mathrm{Mg} \mathrm{ha}^{-1}\right.$ ) estimated after the 2007 Egley Fire Complex, eastern Oregon, USA, for (A) 2008 and (B) 2016, contrasting treatmentseverity groups; $\mathrm{T}$ = treated, $\mathrm{U}=$ untreated. Standard error bars are for total surface fuels (all fuel components added together). Lowercase letters below error bars denote significant Tukey multiple comparisons for fine woody debris and the asterisk (*) above error bars denote significant Tukey multiple comparisons, $P<0.05$, between treatment and severity groups for coarse woody debris 
Table 3 Blocked multi-response permutation procedure (MRBP) tests comparing 2008 variables to 2016 variables measured after the 2007 Egley Fire Complex in eastern, Oregon, USA. Boldface $P$-values denotes significance at the 95\% confidence level, whereas boldface $A$-values are above 0.3 (strong within group agreement), and SE denotes the standard error within each group. NPV = non-photosynthetic (dead or dormant) vegetation; CWD = coarse woody debris

\begin{tabular}{|c|c|c|c|c|}
\hline Variable description & $P$ & $A$ & 2008 Mean (SE) & 2016 Mean (SE) \\
\hline Tree canopy cover (\%) & $<0.001$ & 0.198 & $40.08(1.56)$ & $28.13(2.61)$ \\
\hline Live tree basal area $\left(\mathrm{m}^{2} \mathrm{ha}^{-1}\right)$ & $<0.001$ & 0.115 & $2.19(0.34)$ & $9.54(1.14)$ \\
\hline Dead tree basal area $\left(\mathrm{m}^{2} \mathrm{ha}^{-1}\right)$ & $<0.001$ & 0.063 & $1.34(0.20)$ & $5.57(0.67)$ \\
\hline Live tree density (stems ha ${ }^{-1}$ ) & $<0.001$ & 0.214 & $298.57(42.10)$ & $140.71(16.82)$ \\
\hline Dead tree density (stems ha ${ }^{-1}$ ) & $<0.001$ & 0.162 & 250.00 (36.33) & $52.86(6.32)$ \\
\hline Live sapling density (stems ha ${ }^{-1}$ ) & 0.036 & 0.012 & $104.29(49.25)$ & $40.00(4.78)$ \\
\hline Dead sapling density (stems $\mathrm{ha}^{-1}$ ) & $<0.001$ & 0.181 & $994.29(176.2)$ & $68.57(8.20)$ \\
\hline Live seedling density (stems $\mathrm{ha}^{-1}$ ) & 0.001 & 0.027 & $571.43(318.72)$ & $236.43(28.26)$ \\
\hline Dead seedling density (stems ha ${ }^{-1}$ ) & 0.081 & 0.008 & 600.00 (392.69) & $7.14(0.85)$ \\
\hline Green vegetation cover (\%) & $<0.001$ & 0.488 & $5.54(0.68)$ & $29.39(3.51)$ \\
\hline NPV cover (\%) & 0.003 & 0.052 & $49.74(2.67)$ & $58.41(6.98)$ \\
\hline Soil and rock cover (\%) & $<0.001$ & 0.421 & $40.70(2.66)$ & $12.00(1.19)$ \\
\hline Char cover (\%) & $<0.001$ & 0.675 & $59.69(2.31)$ & $7.34(0.88)$ \\
\hline Moss, lichen, and fungi cover (\%) & $<0.001$ & 0.122 & $1.76(0.78)$ & $2.31(0.28)$ \\
\hline Shrub cover (\%) & $<0.001$ & 0.106 & $0.94(0.35)$ & $6.53(0.78)$ \\
\hline Graminoid cover (\%) & $<0.001$ & 0.356 & $4.47(0.77)$ & $14.15(1.69)$ \\
\hline Forb cover (\%) & $<0.001$ & 0.117 & $7.14(1.05)$ & $10.92(1.31)$ \\
\hline Invasive cover (\%) & $<0.001$ & 0.151 & $0.10(0.09)$ & $2.42(0.29)$ \\
\hline Total fuel loads $\left(\mathrm{Mg} \mathrm{ha}^{-1}\right)$ & $<0.001$ & 0.094 & $17.98(2.39)$ & $30.07(3.59)$ \\
\hline Fine fuel loads $\left(\mathrm{Mg} \mathrm{ha}^{-1}\right)$ & $<0.001$ & 0.110 & $7.21(0.72)$ & $11.00(1.31)$ \\
\hline CWD $\left(\mathrm{Mg} \mathrm{ha}^{-1}\right)$ & 0.002 & 0.053 & $10.78(3.19)$ & $19.07(2.28)$ \\
\hline 100-hour fuels (Mg ha ${ }^{-1}$ ) & 0.008 & 0.034 & $1.69(0.42)$ & $1.31(0.16)$ \\
\hline 10-hour fuels (Mg ha-1) & 0.001 & 0.055 & $0.66(0.12)$ & $1.16(0.14)$ \\
\hline 1-hour fuels $\left(\mathrm{Mg} \mathrm{ha}^{-1}\right)$ & $<0.001$ & 0.410 & $0.02(0.00)$ & $0.32(0.04)$ \\
\hline Litter $\left(\mathrm{Mg} \mathrm{ha}^{-1}\right)$ & $<0.001$ & 0.404 & $1.68(0.22)$ & $6.08(0.73)$ \\
\hline Duff $\left(\mathrm{Mg} \mathrm{ha}^{-1}\right)$ & 0.052 & 0.019 & $3.16(0.41)$ & $2.14(0.26)$ \\
\hline
\end{tabular}

Tree canopy cover, live and dead tree density, and live and dead sapling density all decreased from 2008 to 2016, but tree basal area, both live and dead, increased over the same time period. This reflects two common land management objectives of decreasing tree density and increasing tree basal area to improve fire resilience. Agee and Skinner (2005) list four principles of increasing fire resistance in dry forests: reduce surface fuels, increase height to live crown, decrease crown density, and keep large fire-resistant tree species. While it is possible that differences in sampling methodology between 2008 and 2016 (8 m versus $11.3 \mathrm{~m}$ radius plots) contributed to the decreases in tree density over time, these decreases also align with expectations of continued mortality and falling of trees post fire.

Seedling density did not differ by treatment or severity in either sample year. The lack of differences seen in seedling density in 2008 between treatment and severity might be attributed to the amount of variability observed in untreated sites that burned at low severity. In 2016, though, the lack of differences in seedling density seen between treatment and severity might be explained by post-fire planting efforts that took place between May 2010 and April 2015. Ten out of the 70 sites sampled had seedlings planted post fire: four treated and six untreated. Eleven out of our 70 sites had an average distance to seed source over $60 \mathrm{~m}$ (data not shown), for which we would expect lower seedling density due to lack of a seed source (Kemp et al. 2016), but seven of these sites had been planted. The significant decrease in live seedling density from 2008 to 2016 might be attributable to reduced overstory protection of seedlings from drought, frost heaving, or other environmental stress (Schubert 1974). 
Surface cover fractions were affected by treatment, severity, and time since fire. The NPV cover fraction that includes both litter, duff, and FWD at untreated sites that burned at low severity were likely not completely consumed and then accumulated from one year post fire to nine years post fire. On the other hand, treated sites that burned with high severity had the lowest NPV cover and more exposed soil and rock cover. Other studies have shown that thinning can cause soil disturbances (Korb et al. 2004; Stephens et al. 2012b), which might explain the higher soil and rock cover found in treated sites in 2008. However, thinning has also been shown to increase FWD (Agee and Skinner 2005; Stephens et al. 2009), which may have been consumed in treated sites that burned at high severity, creating more soil and rock exposure (Graham et al. 1999; Hille and Stephens 2005).

Cover of understory vegetation functional groups followed similar patterns as surface cover materials. The only functional group that was affected by severity in 2008 was shrub cover, which was higher in sites that burned with low severity than high severity. It is not uncommon for forb, graminoid, and shrub cover to decrease one to three years post fire (Metlen et al. 2004; Collins et al. 2007; Knapp et al. 2007; Dodson et al. 2008); however, some studies have shown increases in understory vegetation cover (Armour et al. 1984; Moore et al. 2006; Ellsworth and Kauffman 2010). Metlen and Fiedler (2006) found that native plant cover was significantly lower initially post fire (same year as the prescribed burn) than unburned sites, however no differences were found in cover one to three years between burned sites and unburned sites in a ponderosa pine-Douglas-fir forest. Armour et al. (1984) found that forb, graminoid, and shrub cover steadily increased one to three years following a prescribed fire in a ponderosa pine forest, with shrubs having the highest percent cover in sites that burned at high intensity. We found similar results nine years post fire, with higher percent cover of shrub, graminoid, and forbs in sites that burned at high severity than in sites that burned at low severity. The increase in percent cover of understory functional groups in high-severity burned sites nine years post fire suggests either on-site vegetation recovery or recolonization between sample years, trends that also apply to green surface cover, although the change in methodology may also account for observed increases. The increase in cover of all understory functional groups from 2008 to 2016, and the increasing trend of LandTrendr-derived NBR from 2008 to 2016 (Fig. 4), indicative of vegetation cover, suggests vegetation recovery across the burn.

In 2016, we found that untreated sites that burned at high severity had more invasive species cover than sites that burned at low severity. Treatments have been shown to increase invasive species cover (Korb et al. 2004; Dodson and Fiedler 2006; Collins et al. 2007; Dodson et al. 2008; Stephens et al. 2012b) as has high burn severity (Turner et al. 1997; Caprio et al. 1999; Griffis et al. 2001; Keeley et al. 2003; Keeley 2006). Although treatments have been shown to increase soil disturbance, leading to an increase in invasive species cover (Korb et al. 2004; Stephens et al. 2012b), we found that high-severity fire, which burned mostly in untreated sites, led to a higher cover of invasive species than did treatments.

Wildfires have been shown to cause vegetation shifts from forested to non-forested vegetation types (Savage and Mast 2005; Crotteau et al. 2013; Dodson and Root 2013; Coop et al. 2016). Savage and Mast (2005) found that, in southwestern US ponderosa pine forests, highseverity burn sites experienced a vegetation shift from ponderosa pine stands to shrub-dominated patches of pointleaf manzanita (Arctostaphylos pungens Kunth). We found higher shrub cover in treated sites that burned at high severity than in treated and untreated sites combined that burned at low severity. Snowbrush ceanothus was a common shrub species found in the Malheur National Forest and Gratkowski (1962) found that snowbrush ceanothus seeds are germinated by heat. Weiner et al. (2016) also found snowbrush ceanothus cover to be higher in areas that burned with high severity in sagebrush steppe and western juniper woodlands. Other studies have found vegetation shifts from ponderosa pinedominant stands to shrub-dominant patches after a high-severity wildfire (Bonnet et al. 2005; Savage and Mast 2005; Coop et al. 2016) and could potentially be occurring at the high-severity burn sites sampled.

Fuel loads, while higher in low-severity burn sites than in high-severity burn sites in 2008, were highest in sites that burned with high severity in 2016. By 2016, sites that experienced high tree mortality (high burn severity) had more downed woody debris accumulation (e.g., fallen snags) than low severity burned sites. Thus, higher surface fuel accumulations were not apparent after just one year but were after nine years. Other studies have shown that tree mortality caused by high-severity wildfire results in heavy surface fuel accumulations at least three years post fire (Passovoy and Fulé 2006; Roccaforte et al. 2012; Stevens-Rumann et al. 2012). The lack of differences found in fuel loads between treated sites that burned at high severity and both treated and untreated sites that burned at low severity suggests that the Egley Fire Complex, following thinning efforts, lowered surface fuels much like a prescribed fire would have. It is important to note that fuel estimates were collected using slightly modified Brown's transects in 2008 (Brown 1974) and photoloads in 2016 (Keane and Dickinson 2007). We opted for the newer, photoload method 
(Keane and Dickinson 2007) of estimating surface fuel loads in 2016 to speed field sampling and in consideration of more recent research that showed that the Brown (1974) method may fail to capture inherently high fuels variability in natural fuel beds (Keane et al. 2012; Vakili et al. 2016). However, Sikkink and Keane (2008) found photoload measurements to overestimate fuel loads (both fine and coarse fuels), especially when a site had high fuel loads $\left(>2 \mathrm{~kg} \mathrm{~m}^{-2}\right)$ in montane forests, which could be occurring here.

It is widely believed that, with the past century of fire suppression, the accumulation of fuels in ponderosa pine forests has led to the increase in large, high-severity fires seen today (Kilgore 1981; Covington and Moore 1994; Allen et al. 2002). Our study confirms that lack of treatments in combination with fire suppression results in a higher likelihood of high-severity fire. While fuel loads in our study did significantly increase from 2008 to 2016, untreated sites that burned with high severity had the highest fuel loads. This suggests that treated sites intersected by the Egley Fire Complex successfully reduced fuel loads for up to nine years post fire and may have met many objectives that Malheur National Forest managers hope to achieve from prescribed fire.

\section{Conclusions}

Fuel reduction treatments implemented 1 to 21 years pre fire were effective at reducing burn severity within a large wildfire. LandTrendr was an effective tool for monitoring vegetation recovery post fire, and regression models of one-year post-fire dNBR significantly predicted biophysical attributes, both in 2008 and 2016, except total fuel loads. The interaction between time since treatment and one-year post-fire dNBR significantly predicted one-year post-fire tree canopy and understory vegetation cover. As burn severity (one-year post-fire $\mathrm{dNBR}$ ) and time since fire increased, one-year post-fire tree canopy and understory green vegetation cover decreased.

Tree canopy cover and basal area was affected more by burn severity than treatments in 2008; however, density of live trees and saplings was more affected by treatment than burn severity. The lower tree and sapling density in pre-fire treated areas likely resulted in the significant reduction in burn severity on treated sites compared to untreated sites. Understory shrub, graminoid, forb, and invasive species cover measured nine years post fire were higher in sites that burned with high severity, as a result of strong vegetation recovery or re-colonization in those sites. Fuel loads in 2016 were higher at untreated sites that burned with high severity than at any other sites, including treated sites that burned at high severity, indicating that thinning, in conjunction with reducing burn severity, reduced surface fuel loads nine years post fire.
The decrease in tree canopy cover and density of trees and saplings, along with the increase in tree basal area from 2008 to 2016, reflects management objectives to reduce fuels via removing small-diameter trees while increasing canopy base height to increase resistance to high-severity fire within the forest. Fuel loads measured in 2016 across the Egley Fire Complex were higher than fuels measured in 2008, indicating post-fire fuel accumulation and suggesting a need for a repeated understory fuel treatment. These results support the implementation of fuel treatments to reduce fire effects in ponderosa pine forests and suggest that low-severity wildfire can accomplish fuel reduction treatment objectives while not overly impacting overstory tree mortality in treated stands.

\section{Acknowledgements}

We want to thank the Forest Service Rocky Mountain Research Station, as well as students at the University of Idaho, who helped gather and enter 2008 field data (C. Craig, M. Holthuijzen, and J. Hulbert) and 2016 field data (J. Byrne, S. McNeal, E. Berman, D. Blanscet, and M. Hernandez). J. Braymen, B. Austin, and M. Bobbitt analyzed the initial burn severity, fuel treatment, and other GIS data. We thank C. Bowman-Prideaux, B. Spei, S. Wozniak, and M. Schmidt for their friendly reviews. We also want to give a special thanks to Dr. P. Morgan for her assistance in project development, field data collection in 2008, and her friendly review.

\section{Authors' contributions}

ATH, EKS, and BAN drafted the study concept and design, as well as developed methods used. All authors assisted in data collection and data analysis. JMD drafted the initial version of the manuscript. All authors participated in critical review and final revision of the manuscript. All authors read and approved the final manuscript.

\section{Funding}

Funding in 2008 was provided by USFS Fire and Aviation Management at the USFS Washington Office through Joint Venture Agreement (JVA) \#03-JV111222065-279 between the USFS Rocky Mountain Research Station (RMRS) and the University of Idaho (UI). Funding in 2016 was provided by Joint Fire Science Program grant \#14-1-02-27 through JVA \#14-JV-11221633-112 and JVA \#17-JV-11221637-132 between RMRS and UI.

\section{Availability of data and materials}

Datasets collected in 2008 (Bright et al. 2019a) and 2016 are publicly available for further analysis (Bright et al. 2019b).

\section{Ethics approval and consent to participate}

Not applicable.

\section{Consent for publication}

Not applicable.

\section{Competing interests}

The authors declare that they have no competing interests.

\section{Author details}

'Department of Forest, Rangeland, and Fire Sciences, University of Idaho, 875 Perimeter Drive, Moscow, Idaho 83844, USA. ${ }^{2}$ Forestry Sciences Laboratory, USFS Rocky Mountain Research Station, 1221 South Main Street, Moscow, Idaho 83843, USA. ${ }^{3}$ Great Basin Rangelands Research, USDA, Agricultural Research Service, 920 Valley Road, Reno, Nevada 89512, USA. 
Received: 8 November 2018 Accepted: 10 September 2019 Published online: 27 November 2019

\section{References}

Abatzoglou, J.T., and A.P. Williams. 2016. Impact of anthropogenic climate change on wildfire across western US forests. Proceedings of the National Academy of Sciences of the United States of America 113: 11770-11775 https://doi.org/10.1073/pnas.1607171113.

Agee, J.K., and C.N. Skinner. 2005. Basic principles of forest fuel reduction treatments. Forest Ecology and Management 211 (1-2): 83-96 https://doi.org/ 10.1016/j.foreco.2005.01.034.

Allen, C.D., M. Savage, D.A. Falk, K.F. Suckling, T.W. Swetnam, T. Schulke, P. B. Stacey, P. Morgan, M. Hoffman, and J.T. Klingel. 2002. Ecological restoration of Southwestern ponderosa pine ecosystems: a broad perspective. Ecological Applications 12 (5): 1418-1433 https://doi.org/10. 1890/1051-0761(2002)012[1418:EROSPP]2.0.CO;2.

Armour, C.D., S.C. Bunting, and L.F. Neuenschwander. 1984. Fire intensity effects on the understory in ponderosa pine forests. Journal of Range Management 37 (1): 44-49 https://doi.org/10.2307/3898822.

Bartuszevige, A.M., and P.L. Kennedy. 2009. Synthesis of knowledge on the effects of fire and thinning treatments on understory vegetation in US dry forests. Special report 1095. Corvallis: Oregon State University Agricultural Experiment Station.

Battaglia, M.A., F.W. Smith, and W.D. Shepperd. 2008. Can prescribed fire be used to maintain fuel treatment effectiveness over time in Black Hills ponderosa pine forests? Forest Ecology and Management 256 (12): 2029-2038 https://doi. org/10.1016/j.foreco.2008.07.026.

Bernau, C.R., E.K. Strand, and S.C. Bunting. 2018. Fuel bed response to vegetation treatments in juniper-invaded sagebrush steppe. Fire Ecology 14: 1-13 https://doi.org/10.1186/s42408-018-0002-z.

Bonnet, V.H., A.W. Schoettle, and W.D. Shepperd. 2005. Postfire environmental conditions influence the spatial pattern of regeneration for Pinus ponderosa. Canadian Journal of Forest Research 35 (1): 37-47 https://doi.org/10.1139/x04-157.

Bradley, A.F., N.V. Noste, and W.C. Fischer. 1992. Fire ecology of forests and woodlands in Utah. USDA Forest Service General Technical Report INT-287 92. Ogden: USDA Forest Service, Intermountain Research Station https://doi.org/ 10.2737/INT-GTR-287

Bright, B.C., A.T. Hudak, and J.M. Dodge. 2019a. Post-fire field observations across the 2007 Egley Fire in central Oregon. Fort Collins: Forest Service Research Data Archive. https://doi.org/10.2737/RDS-2019-0015

Bright, B.C., A.T. Hudak, E.K. Strand, B.A. Newingham, A.G. Smith, D.H. Hammond, J.M. Dodge, and J. Bontrager. 2019b. Field attributes and satellite data for "How vegetation recovery and fuel conditions in past fires influences fuels and future fire management in five western US ecosystems". Fort Collins: Forest Service Research Data Archive https://doi.org/10.2737/RDS-2019-0005.

Brown, J.K. 1974. Handbook for inventorying downed woody material. USDA Forest Service, General Technical Report INT-16. Ogden: USDA Forest Service, Intermountain Forest and Range Experiment Station.

Caprio, A., S. Haultain, M. Keifer, and J. Manley. 1999. Problem evaluation and recommendations: invasive cheatgrass (Bromus tectorum) in Cedar Grove, Kings Canyon National Park. Three Rivers: Sequoia and Kings Canyon National Parks, Science and Natural Resource Division.

Chung, W. 2015. Optimizing fuel treatments to reduce wildland fire risk. Current Forestry Reports 1 (1): 44-51 https://doi.org/10.1007/s40725-015-0005-9.

Collins, B.M., J.J. Moghaddas, and S.L. Stephens. 2007. Initial changes in forest structure and understory plant communities following fuel reduction activities in a Sierra Nevada mixed conifer forest. Forest Ecology and Management 239: 102-111 https://doi.org/10.1016/j.foreco.2006.11.013.

Coop, J.D., S.A. Parks, S.R. McClernan, and L.M. Holsinger. 2016. Influences of prior wildfires on vegetation response to subsequent fire in a reburned Southwestern landscape. Ecological Applications 26 (2): 346-354 https://doi. org/10.1890/15-0775

Cooper, C.F. 1960. Changes in vegetation, structure, and growth of Southwestern pine forests since white settlement. Ecological Monographs 30 (2): 129-164 https://doi.org/10.2307/1948549.

Covington, W.W., and M.M. Moore. 1994. Post settlement changes in natural fire regimes and forest structure: ecological restoration of old-growth ponderosa pine forests. Journal of Sustainable Forestry 2: 153-181 https:// doi.org/10.1300/J091v02n01_07.
Cribari-Neto, F., and A. Zeileis. 2010. Beta regression in R. Journal of Statistical Software 34: 1-24 https://doi.org/10.18637/jss.v034.i02

Crotteau, J.S., J.M. Varner III, and M.W. Ritchie. 2013. Post-fire regeneration across a fire severity gradient in the southern Cascades. Forest Ecology and Management 287: 103-112 https://doi.org/10.1016/j.foreco.2012.09.022.

Dodson, E.K., and C.E. Fiedler. 2006. Impacts of restoration treatments on alien plant invasion in Pinus ponderosa forests, Montana, USA. Journal of Applied Ecology 43 (5): 887-897 https://doi.org/10.1111/j.1365-2664.2006.01206.x.

Dodson, E.K., D.W. Peterson, and R.J. Harrod. 2008. Understory vegetation response to thinning and burning restoration treatments in dry conifer forests of the eastern Cascades, USA. Forest Ecology and Management 255: 3130-3140 https://doi.org/10.1016/j.foreco.2008.01.026.

Dodson, E.K., and H.T. Root. 2013. Conifer regeneration following stand-replacing wildfire varies along an elevation gradient in a ponderosa pine forest, Oregon, USA. Forest Ecology and Management 302: 163-170 https://doi.org/ 10.1016/j.foreco.2013.03.050

Eidenshink, J., B. Schwind, K. Brewer, Z.-L. Zhu, B. Quayle, and S. Howard. 2007. A project for monitoring trends in burn severity. Fire Ecology 3 (1): 3-21 https:// doi.org/10.4996/fireecology.0301003.

Ellsworth, L.M., and J.B. Kauffman. 2010. Native bunchgrass response to prescribed fire in ungrazed mountain big sagebrush ecosystems. Fire Ecology 6 (3): 86-96 https://doi.org/10.4996/fireecology.0603086.

Finney, M.A., C.W. McHugh, and I.C. Grenfell. 2005. Stand- and landscape-level effects of prescribed burning on two Arizona wildfires. Canadian Journal of Forest Research 35 (7): 1714-1722 https://doi.org/10.1139/x05-090.

Fulé, P.Z., W.W. Covington, and M.M. Moore. 1997. Determining reference conditions for ecosystem management of Southwestern ponderosa pine forests. Ecological Applications 7 (3): 895-908 https://doi.org/10.1890/10510761(1997)007[0895:DRCFEM]2.0.CO;2.

Fulé, P.Z., J.E. Crouse, J.P. Roccaforte, and E.L. Kalies. 2012. Do thinning and/or burning treatments in western USA ponderosa or Jeffrey pine-dominated forests help restore natural fire behavior? Forest Ecology and Management 269: 68-81 https://doi.org/10.1016/j.foreco.2011.12.025.

Fulé, P.Z., D.C. Laughlin, and W.W. Covington. 2005. Pine-oak forest dynamics five years after ecological restoration treatments, Arizona, USA. Forest Ecology and Management 218: 129-145 https://doi.org/10.1016/j.foreco.2005.07.005.

Fulé, P.Z., J.P. Roccaforte, and W.W. Covington. 2007. Posttreatment tree mortality after forest ecological restoration, Arizona, United States. Environmental Management 40 (4): 623-634 https://doi.org/10.1007/s00267-006-0374-8.

Gorelick, N., M. Hancher, M. Dixon, S. Ilyushchenko, D. Thau, and R. Moore. 2017. Google Earth Engine: planetary-scale geospatial analysis for everyone. Remote Sensing of Environment 202: 18-27 https://doi.org/10.1016/j.rse.2017.06.031.

Gorte, R. 2013. The rising cost of wildfire protection. Bozeman: Headwaters Economics.

Graham, R.T., A.E. Harvey, T.B. Jain, and J.R. Tonn. 1999. The effects of thinning and similar stand treatments on fire behavior in Western forests. USDA Forest Service General Technical Report PNW-GTR-463. Portland: USDA Forest Service, Pacific Northwest Research Station https://doi.org/10.2737/PNW-GTR-463.

Gratkowski, H.J. 1962. Heat as a factor in germination of seeds of Ceanothus velutinus var. leavigatus T. \& G. Thesis. Oregon State University, Corvallis, Oregon, USA.

Griffis, K.L., J.A. Crawford, M.R. Wagner, and W.H. Moir. 2001. Understory response to management treatments in northern Arizona ponderosa pine forests. Forest Ecology and Management 146: 239-245 https://doi.org/10.1016/S03781127(00)00461-8.

Groffman, P.M., J.S. Baron, T. Blett, A.J. Gold, I. Goodman, L.H. Gunderson, B.M. Levinson, M.A. Palmer, H.W. Paerl, G.D. Peterson, N.L. Poff, D.W. Rejeski, J.F. Reynolds, M.G. Turner, K.C. Weathers, and J. Wiens. 2006. Ecological thresholds: the key to successful environmental management or an important concept with no practical application? Ecosystems 9 (1): 1-13 https://doi.org/10.1007/s10021-003-0142-z.

Hardy, C.C., R.D. Ottmar, J.L. Peterson, J.E. Core, and P. Seamon, eds. 2001. Smoke management guide for prescribed and wildland fire: 2001 edition. PMS 420-2. NFES 1279. Boise: National Wildfire Coordination Group.

Haskins, K.E., and C.A. Gehring. 2004. Long-term effects of burning slash on plant communities and arbuscular mycorrhizae in a semi-arid woodland. Journal of Applied Ecology 41 (2): 379-388 https://doi.org/10.1111/j.0021-8901.2004.00889.x.

Hessburg, P.F., J.K. Agee, and J.F. Franklin. 2005. Dry forests and wildland fires of the inland northwest USA: contrasting the landscape ecology of the presettlement and modern eras. Forest Ecology and Management 211: 117-139 https://doi.org/10.1016/j.foreco.2005.02.016. 
Hille, M.G., and S.L. Stephens. 2005. Mixed conifer forest duff consumption during prescribed fires: tree crown impacts. Forest Science 51 (5): 417-424.

Holling, C.S. 1973. Resilience and stability of ecological systems. Annual Review of Ecology and Systematics 4: 1-23 https:/doi.org/10.1146/annurev.es.04.110173.000245.

Hudak, A.T., T.B. Jain, P. Morgan, and J.T. Clark. 2011a. Remote sensing of WUI fuel treatment effectiveness following the 2007 wildfires in central Idaho. In Proceedings of the 3rd fire behavior and fuels conference, October 25-29, 2010, Spokane, Washington, USA, ed. D.D. Wade and M.L. Robinson, 1-11. Birmingham: International Association of Wildland Fire.

Hudak, A.T., P. Morgan, M.J. Bobbitt, A.M.S. Smith, S.A. Lewis, L.B. Lentile, P.R. Robichaud, J.T. Clark, and R.A. McKinley. 2007. The relationship of multispectral satellite imagery to immediate fire effects. Fire Ecology 3 (1): $64-$ 90 https://doi.org/10.4996/fireecology.0301064.

Hudak, A.T., I. Rickert, P. Morgan, E.K. Strand, S.A. Lewis, P.R. Robichaud, C. M. Hoffman, and Z.A. Holden. 2011b. Review of fuel treatment effectiveness in forests and rangelands and a case study from the 2007 megafires in central Idaho, USA. USDA Forest Service General Technical Report RMRS-GTR-2. Fort Collins: USDA Forest Service, Rocky Mountain Research Station https://doi.org/10.2737/RMRS-GTR-252.

Kalies, E.L., and L.L. Yocom Kent. 2016. Tamm review: are fuel treatments effective at achieving ecological and social objectives? A systematic review. Forest Ecology and Management 375: 84-95 https://doi.org/10. 1016/j.foreco.2016.05.021.

Kane, J.M., J.M. Varner, E.E. Knapp, and R.F. Powers. 2010. Understory vegetation response to mechanical mastication and other fuels treatments in a ponderosa pine forest. Applied Vegetation Science 13 (2): 207-220 https://doi. org/10.1111/j.1654-109X.2009.01062.x.

Keane, R.E., and L.J. Dickinson. 2007. The photoload sampling technique: estimating surface fuel loadings from downward-looking photographs of synthetic fuelbeds. USDA Forest Service General Technical Report RMRO-GTR190. Fort Collins: USDA Forest Service, Rocky Mountain research Station https://doi.org/10.2737/RMRS-GTR-190.

Keane, R.E., K. Gray, V. Bacciu, and S. Leirfallom. 2012. Spatial scaling of wildland fuels for six forest and rangeland ecosystems of the northern Rocky Mountains, USA. Landscape Ecology 27 (8): 1213-1234 https://doi.org/10. 1007/s10980-012-9773-9.

Keeley, J.E. 2006. Fire management impacts on invasive plants in the western United States. Conservation Biology 20 (2): 375-384 https://doi.org/10.1111/j. 1523-1739.2006.00339.x.

Keeley, J.E. 2009. Fire intensity, fire severity and burn severity: a brief review and suggested usage. International Journal of Wildland Fire 18 (1): 116-126 https://doi.org/10.1071/WF07049.

Keeley, J.E., D. Lubin, and C.J. Fotheringham. 2003. Fire and grazing impacts on plant diversity and alien plant invasions in the southern Sierra Nevada. Ecological Applications 13 (5): 1355-1374 https://doi.org/10.1890/02-5002.

Kemp, K.B., P.E. Higuera, and P. Morgan. 2016. Fire legacies impact conifer regeneration across environmental gradients in the US northern Rockies. Landscape Ecology 31 (3): 619-636 https://doi.org/10.1007/s10980-015-0268-3.

Kennedy, R.E., Z. Yang, and W.B. Cohen. 2010. Detecting trends in forest disturbance and recovery using yearly Landsat time series: 1. LandTrendr-temporal segmentation algorithms. Remote Sensing of Environment 114 (12): 2897-2910 https://doi.org/10.1016/j.rse.2010.07.008.

Kennedy, R.E., Z. Yang, N. Gorelick, J. Braaten, L. Cavalcante, W.B. Cohen, and S. Healey. 2018. Implementation of the LandTrendr algorithm on Google Earth Engine. Remote Sensing 10 (5): 691 https://doi.org/10.3390/rs10050691.

Key, C.H., and N.C. Benson. 2006. Landscape assessment: sampling and analysis methods. USDA Forest Service General Technical Report RMRS-GTR-164-CD. Fort Collins: USDA Forest Service, Rocky Mountain Research Station.

Kilgore, B.M. 1981. Fire in ecosystem distribution and structure: Western forests and scrublands. In Proceedings of the conference, fire regimes and ecosystem properties. USDA Forest Service General Technical Report WO-GTR-26, ed. H.A. Mooney, T.M. Bonnickson, N.L. Christensen, J.E. Lotan, and B.H. Honkala, 5889. Washington, D.C.: US Department of Agriculture, Forest Service.

Knapp, E.E., D.W. Schwilk, J.M. Kane, and J.E. Keeley. 2007. Role of burning season on initial understory vegetation response to prescribed fire in a mixed conifer forest. Canadian Journal of Forest Research 37 (1): 11-22 https://doi. org/10.1139/x06-200.

Korb, J.E., N.C. Johnson, and W.W. Covington. 2004. Slash pile burning effects on soil biotic and chemical properties and plant establishment: recommendations for amelioration. Restoration Ecology 12 (1): 52-62 https:// doi.org/10.1111/j.1061-2971.2004.00304.X.
Lentile, L.B., A.M.S. Smith, A.T. Hudak, P. Morgan, and M.J. Bobbitt. 2009. Remote sensing for prediction of 1-year post-fire ecosystem condition. International Journal of Wildland Fire 18 (5): 594-608 https://doi.org/10.1071/WF07091.

Lentile, L.B., F.W. Smith, and W.D. Shepperd. 2006. Influence of topography and forest structure on patterns of mixed severity fire in ponderosa pine forests of the South Dakota Black Hills, USA. International Journal of Wildland Fire 15 (4): 557-566 https://doi.org/10.1071/WF05096.

Littell, J.S., D. McKenzie, D.L. Peterson, and A.L. Westerling. 2009. Climate and wildfire area burned in western US ecoprovinces, 1916-2003. Ecological Applications 19 (4): 1003-1021 https://doi.org/10.1890/07-1183.1.

McCune, B. 1988. Ecological diversity in North American pines. American Journal of Botany 75 (3): 353-368 https://doi.org/10.1002/j.1537-2197.1988.tb13450.x.

McCune, B., and J.B. Grace. 2002. Analysis of ecological communities. Gleneden Beach: MjM Software Design.

McCune, B., and M.J. Mefford. 2016. PC-ORD: multivariate analysis of ecological data. Gleneden Beach: MjM Software Design.

Metlen, K.L., and C.E. Fiedler. 2006. Restoration treatment effects on the understory of ponderosa pine/Douglas-fir forests in western Montana, USA. Forest Ecology and Management 222: 355-369 https://doi.org/10.1016/j. foreco.2005.10.037.

Metlen, K.L., C.E. Fiedler, and A. Youngblood. 2004. Understory response to fuel reduction treatments in the Blue Mountains of northeastern Oregon. Northwest Science 78: 175-185.

Moore, M.M., C.A. Casey, J.D. Bakker, J.D. Springer, P.Z. Fulé, W.W. Covington, and D.C. Laughlin. 2006. Herbaceous vegetation responses (1992-2004) to restoration treatments in a ponderosa pine. Rangeland Ecology \& Management 59 (2): 135-144 https://doi.org/10.2458/azu_jrm_v59i2_moore.

Morgan, P., C.C. Hardy, T.W. Swetnam, M.G. Rollins, and D.G. Long. 2001. Mapping fire regimes across time and space: understanding coarse and fine-scale fire patterns. International Journal of Wildland Fire 10 (4): 329-342 https://doi.org/ 10.1071/WF01032.

Nelder, J., and W. Wedderburn. 1972. Generalized linear models. Journal of the Royal Statistical Society, Series A 135: 370-384 https://doi.org/10.2307/ 2344614.

Parsons, A., and A. Orlemann. 2002. Mapping post-wildfire burn severity using remote sensing and GIS. In Proceedings of the 22nd annual ESRI International user conference, 8-12 July 2002, San Diego, CA, 1-9. Redlands: ESRI Press.

Passovoy, M.D., and P.Z. Fulé. 2006. Snag and woody debris dynamics following severe wildfires in northern Arizona ponderosa pine forests. Forest Ecology and Management 223: 237-246 https://doi.org/10.1016/j.foreco.2005.11.016.

Peña, E.A., and E.H. Slate. 2006. Global validation of linear models assumptions. Journal of the American Statistical Association 101 (473): 341-354 https://doi. org/10.1198/016214505000000637.

Prichard, S.J., D.L. Peterson, and K. Jacobson. 2010. Fuel treatments reduce the severity of wildfire effects in dry mixed conifer forest, Washington, USA. Canadian Journal of Forest Research 40 (8): 1615-1626 https://doi.org/10. 1139/X10-109.

$R$ Core Team. 2013. R: a language and environment for statistical computing. Vienna: R Foundation for Statistical Computing http://www.R-project.org/.

Roccaforte, J.P., P.Z. Fulé, W.W. Chancellor, and D.C. Laughlin. 2012. Woody debris and tree regeneration dynamics following severe wildfires in Arizona ponderosa pine forests. Canadian Journal of Forest Research 42 (3): 593-604 https://doi.org/10.1139/×2012-010.

Savage, M., and J.N. Mast. 2005. How resilient are Southwestern ponderosa pine forests after crown fires? Canadian Journal of Forest Research 35 (4): 967-977 https://doi.org/10.1139/×05-028.

Schubert, G.H. 1974. Silviculture of Southwestern ponderosa pine: the status of our knowledge. USDA Forest Service Research Paper RM-123. Fort Collins: USDA Forest Service, Rocky Mountain Forest and Range Experiment Station https://doi.org/10.5962/bhl.title.98816.

Schwilk, D.W., J.E. Keeley, E.E. Knapp, J. Mclver, J.D. Bailey, C.J. Fettig, C. Fiedler, RJ. Harrod, J.. Moghaddas, K.W. Outcalt, C.N. Skinner, S.L. Stephens, T.A. Waldrop, D. A. Yaussy, and A. Youngblood. 2009. The national Fire and Fire Surrogate study: effects of fuel reduction methods on forest vegetation structure and fuels. Ecological Applications 19 (2): 285-304 https:/doi.org/10.1890/07-1747.1.

Sikkink, P.G., and R.E. Keane. 2008. A comparison of five sampling techniques to estimate surface fuel loading in montane forests. International Journal of Wildland Fire 17 (3): 363-379 https://doi.org/10.1071/WF07003.

Stephens, S.L., B.M. Collins, and G. Roller. 2012a. Fuel treatment longevity in a Sierra Nevada mixed conifer forest. Forest Ecology and Management 285: 204-212 https://doi.org/10.1016/j.foreco.2012.08.030. 
Stephens, S.L., M.A. Finney, and H. Schantz. 2004. Bulk density and fuel loads of ponderosa pine and white fir forest floors: impacts of leaf morphology. Northwest Science 78: 93-100.

Stephens, S.L., J.D. Mclver, R.E.J. Boerner, C.J. Fettig, J.B. Fontaine, B.R. Hartsough, P.L. Kennedy, and D.W. Schwilk. 2012b. The effects of forest fuel-reduction treatments in the United States. BioScience 62 (6): 549-560 https://doi.org/10. 1525/bio.2012.62.6.6

Stephens, S.L., J.J. Moghaddas, C. Edminster, C.E. Fiedler, S. Haase, M.G. Harrington, J.E. Keeley, E.E. Knapp, J.D. Mclver, K. Metlen, C.N. Skinner, and A. Youngblood. 2009. Fire treatment effects on vegetation structure, fuels, and potential fire severity in western US forests. Ecological Applications 19 (2): 305-320 https://doi.org/10.1890/07-1755.1.

Stephens, S.L., and L.W. Ruth. 2005. Federal forest-fire policy in the United States. Ecological Applications 15 (2): 532-542 https://doi.org/10.1890/04-0545.

Stevens-Rumann, C.S., C.H. Sieg, and M.E. Hunter. 2012. Ten years after wildfires: how does varying tree mortality impact fire hazard and forest resiliency? Forest Ecology and Management 267: 199-208 https://doi.org/10.1016/j. foreco.2011.12.003.

Tinkham, W.T., C.M. Hoffman, S.A. Ex, M.A. Battaglia, and J.D. Saralecos. 2016 Ponderosa pine forest restoration treatment longevity: implications of regeneration on fire hazard. Forests 7 (7): 137 https://doi.org/10.3390/ f7070137.

Turner, M.G., W.H. Romme, R.H. Gardner, and W.W. Hargrove. 1997. Effects of fire size and pattern on early succession in Yellowstone National Park. Ecological Monographs 67 (4): 411-433 https://doi.org/10.1890/00129615(1997)067[0411:EOFSAP]2.0.CO:2.

US Climate Data. 2019. US climate data: temperature, precipitation, sunshine, snowfall. https://www.usclimatedata.com/climate/burns/oregon/unitedstates/usor0047. Accessed 19 May 2018.

Vaillant, N.M., J. Fites-Kaufman, A.L. Reiner, E.K. Noonan-Wright, and S.N. Dailey. 2009. Effectiveness of fuel treatments on fuels and potential fire behavior in California, USA, national forests. Fire Ecology 5 (2): 14-29 https://doi.org/10. 4996/fireecology.0502014.

Vakili, E., C.M. Hoffman, R.E. Keane, W.T. Tinkham, and Y. Dickinson. 2016. Spatial variability of surface fuels in treated and untreated ponderosa pine forests of the southern Rocky Mountains. International Journal of Wildland Fire 25 (11): 1156-1168 https://doi.org/10.1071/WF16072.

van Wagtendonk, J.W., R.R. Root, and C.H. Key. 2004. Comparison of AVIRIS and Landsat ETM+ detection capabilities for burn severity. Remote Sensing of Environment 92 (3): 397-408 https://doi.org/10.1016/j.rse.2003.12.015.

Weiner, N.I., E.K. Strand, S.C. Bunting, and A.M.S. Smith. 2016. Duff distribution influences fire severity and post-fire vegetation recovery in sagebrush steppe. Ecosystems 19 (7): 1196-1209 https://doi.org/10.1007/s10021-016-9994-x.

Westerling, A.L., H.G. Hidalgo, D.R. Cayan, and T.W. Swetnam. 2006. Warming and earlier spring increase western US forest wildfire activity. Science 313 (5789): 940-943 https://doi.org/10.1126/science.1128834.

Woodall, C.W., and V.J. Monleon. 2006. Estimating the quadratic mean diameter of fine woody debris for forest type groups of the United States. In Proceedings of the eighth annual forest inventory and analysis symposium. USDA Forest Service General Technical Report WO-79, ed. R.E. McRoberts, G.A. Reams, P.C. Van Deusen, and W.H. McWilliams, 185-190. Washington, D.C.: US Department of Agriculture, Forest Service https://doi.org/10.2737/WO-GTR-79.

Yoder, J., D. Engle, and S. Fuhlendorf. 2004. Liability, incentives, and prescribed fire for ecosystem management. Frontiers in Ecology and the Environment 2 (7): 361-366 https://doi.org/10.2307/3868361.

\section{Publisher's Note}

Springer Nature remains neutral with regard to jurisdictional claims in published maps and institutional affiliations.

\section{Submit your manuscript to a SpringerOpen ${ }^{\circ}$ journal and benefit from:}

- Convenient online submission

- Rigorous peer review

- Open access: articles freely available online

- High visibility within the field

- Retaining the copyright to your article

Submit your next manuscript at $\boldsymbol{\nabla}$ springeropen.com 